\title{
Dopamine-Galanin Receptor Heteromers Modulate Cholinergic Neurotransmission in the Rat Ventral Hippocampus
}

\author{
Estefanía Moreno, ${ }^{1,2 *}$ Sandra H. Vaz,,${ }^{3,4 *}$ Ning-Sheng Cai, ${ }^{5}$ Carla Ferrada, ${ }^{1,2}$ César Quiroz, ${ }^{5}$ Sandeep Kumar Barodia,,${ }^{5}$ \\ Nadine Kabbani, ${ }^{6}$ Enric I. Canela, ${ }^{1,2}$ Peter J. McCormick, ${ }^{1,2}$ Carme Lluis, ${ }^{1,2}$ Rafael Franco, ${ }^{1,2,7}$ Joaquim A. Ribeiro, ${ }^{3,4}$ \\ Ana M. Sebastião, ${ }^{3,4 * *}$ and Sergi Ferré ${ }^{5 * *}$ \\ ${ }^{1}$ Centro de Investigación Biomédica en Red sobre Enfermedades Neurodegenerativas and ${ }^{2}$ Faculty of Biology, Department of Biochemistry and Molecular \\ Biology, University of Barcelona, 08028 Barcelona, Spain, ${ }^{3}$ Faculty of Medicine, Institute of Pharmacology and Neurosciences, and ${ }^{4}$ Unit of Neuroscience, \\ Institute of Molecular Medicine, University of Lisbon, 1649-028 Lisbon, Portugal, ${ }^{5}$ Intramural Research Program, National Institute on Drug Abuse, \\ Department of Health and Human Services, National Institutes of Health, Baltimore, Maryland 21224, ${ }^{6}$ Department of Molecular Neuroscience, Krasnow \\ Institute for Advanced Study, Fairfax, Virginia 22030, and ${ }^{7}$ Centro de Investigación Médica Aplicada, Universidad de Navarra, 31008 Pamplona, Spain
}

Previous studies have shown that dopamine and galanin modulate cholinergic transmission in the hippocampus, but little is known about the mechanisms involved and their possible interactions. By using resonance energy transfer techniques in transfected mammalian cells, we demonstrated the existence of heteromers between the dopamine $\mathrm{D}_{1}$-like receptors $\left(\mathrm{D}_{1}\right.$ and $\left.\mathrm{D}_{5}\right)$ and galanin Gal ${ }_{1}$, but not Gal receptors. Within the $\mathrm{D}_{1}-\mathrm{Gal}_{1}$ and $\mathrm{D}_{5}-\mathrm{Gal}_{1}$ receptor heteromers, dopamine receptor activation potentiated and dopamine receptor blockade counteracted MAPK activation induced by stimulation of $\mathrm{Gal}_{1}$ receptors, whereas $\mathrm{Gal}_{1}$ receptor activation or blockade did not modify $\mathrm{D}_{1}$-like receptor-mediated MAPK activation. Ability of a $\mathrm{D}_{1}$-like receptor antagonist to block galanin-induced MAPK activation (cross-antagonism) was used as a "biochemical fingerprint" of $\mathrm{D}_{1}$-like-Gal ${ }_{1}$ receptor heteromers, allowing their identification in the rat ventral hippocampus. The functional role of $\mathrm{D}_{1}$-like-Gal receptor heteromers was demonstrated in synaptosomes from rat ventral hippocampus, where galanin facilitated acetylcholine release, but only with costimulation of $\mathrm{D}_{1}$-like receptors. Electrophysiological experiments in rat ventral hippocampal slices showed that these receptor interactions modulate hippocampal synaptic transmission. Thus, a $\mathrm{D}_{1}$-like receptor agonist that was ineffective when administered alone turned an inhibitory effect of galanin into an excitatory effect, an interaction that required cholinergic neurotransmission. Altogether, our results strongly suggest that $\mathrm{D}_{1}$-like-Gal ${ }_{1}$ receptor heteromers act as processors that integrate signals of two different neurotransmitters, dopamine and galanin, to modulate hippocampal cholinergic neurotransmission.

\section{Introduction}

The neuropeptide galanin is widely distributed in the CNS (Melander et al., 1986a,b; Hökfelt et al., 1998; Ögren et al., 1998), where it is coreleased with noradrenaline, serotonin, histamine, and acetylcholine (ACh) (Hökfelt et al., 1998). Particular atten-

Received Jan. 12, 2011; revised March 31, 2011; accepted April 5, 2011.

Author contributions: N.K., E.I.C.,P.J.M., C.L., R.F., J.A.R., A.M.S., and S.F. designed research; E.M., S.H.V., N.-S.C., C.F., and S.B. performed research; E.M., S.H.V., N.-S.C., C.Q., S.B., C.L., A.M.S., and S.F. analyzed data; P.J.M., C.L., J.A.R., A.M.S., and S.F. wrote the paper.

This work was supported by the Spanish Ministerio de Ciencia y Tecnología (Grants SAF2008-03229-E, SAF200907276 and SAF2010-18472), the intramural funds of the National Institute on Drug Abuse, EU (Cost B-30 concerted action), and Fundação para a Ciência e Tecnologia (FCT, Portugal). S.H.V. is in receipt of a FCT PhD fellowship (SFRHBD/27989/2006). P.J.M. is a Ramon y Cajal Investigator. We acknowledge the technical help obtained from Jasmina Jiménez (Molecular Neurobiology laboratory, Barcelona University, Barcelona).

${ }^{*}$ E.M. and S.H.V. contributed equally to this work.

${ }^{* *}$ A.M.S. and S.F. contributed equally to this work.

The authors declare no competing financial interests.

Correspondence should be addressed to Sergi Ferré, National Institute on Drug Abuse, Intramural Research

Program, Department of Health and Human Services, NIH, 251 Bayview Boulevard, Baltimore MD 21224. E-mail: sferre@intra.nida.nih.gov.

DOI:10.1523/JNEUROSCI.0191-11.2011

Copyright $@ 2011$ the authors $\quad 0270-6474 / 11 / 317412-12 \$ 15.00 / 0$ tion has been given to the presence of galanin in a population of cholinergic neurons in the septal nucleus and diagonal band of Broca, which project to the hippocampal formation (Melander et al., 1985), because of its possible relevance for learning, memory, and Alzheimer's disease (Ögren et al., 1998; Mitsukawa et al., 2008). $\mathrm{Gal}_{1}$ and $\mathrm{Gal}_{2}$ receptors are the predominant galanin receptor subtypes in the brain and, together with the less populated subtype $\mathrm{Gal}_{3}$, they belong to the G-protein-coupled receptor (GPCR) family (Branchek et al., 2000). The lack of selective ligands and reliable antibodies (Hawes and Picciotto, 2005) has made it difficult to identify the distribution of $\mathrm{Gal}_{1}$ and $\mathrm{Gal}_{2}$ receptors in the septohippocampal system. Gal ${ }_{1}$ mRNA is highly expressed in the septal area, where $\mathrm{Gal}_{2}$ mRNA expression is moderate and confined to a few scattered neurons (Parker et al., 1995; O’Donnell et al., 1999). ${ }^{125}$ I-galanin binding sites in the ventral hippocampus are significantly reduced after lesions of the septohippocampal projection, which eliminates most cholinergic input to the ventral hippocampus (Fisone et al., 1987). This provided clear evidence for the existence of a significant population of presynaptic hippocampal galanin receptors localized in cho- 
linergic nerve terminals, although the galanin receptor subtype involved is still a matter of debate (Miller et al., 1997). With postsynaptic galanin receptors, $\mathrm{Gal}_{1}$ is preferentially expressed in the ventral hippocampus, CA1, and subiculum, whereas $\mathrm{Gal}_{2}$ is expressed in the dentate gyrus of both ventral and dorsal hippocampus (O’Donnell et al., 1999).

In vivo studies in rodents with central administration of galanin have suggested that galanin inhibits cholinergic neurotransmission in the ventral hippocampus (Fisone et al., 1987; Ögren et al., 1998; Laplante et al., 2004a). Furthermore, central administration of galanin leads to cognitive deficits in a variety of tasks (Crawley, 1996; Ögren et al., 1998). However, recent postmortem studies on brains from Alzheimer's disease patients suggest that galanin may instead stimulate cholinergic neurotransmission, which could attenuate the development of Alzheimer's symptoms (Counts et al., 2008; Ögren et al., 2010).

In addition to galanin, dopamine also plays a key modulatory role in the septohippocampal cholinergic pathway. Initial studies showed that dopamine facilitates hippocampal ACh release by acting on $\mathrm{D}_{1}$-like receptors that are thought to be located in hippocampal cholinergic terminals (Hersi et al., 1995). Of the two $\mathrm{D}_{1}$-like receptor subtypes, $\mathrm{D}_{1}$ and $\mathrm{D}_{5}, \mathrm{D}_{5}$ is the predominant subtype in the hippocampus (Ciliax et al., 2000) and the one most probably involved in the modulation of hippocampal ACh release (Hersi et al., 2000; Laplante et al., 2004b). In the present study, we demonstrate that dopamine and galanin work in concert to modulate cholinergic neurotransmission in the ventral hippocampus and that this modulation can occur via heteromers between $\mathrm{D}_{1}$ or $\mathrm{D}_{5}$ receptors and $\mathrm{Gal}_{1}$ receptors.

\section{Materials and Methods}

Animals. Male Wistar rats (4-7 weeks old) from Harlan Interfauna Iberica were housed in a temperature- $\left(21 \pm 1^{\circ} \mathrm{C}\right)$ and humiditycontrolled ( $55 \pm 10 \%)$ room with a $12 \mathrm{~h}$ light/dark cycle with food and water ad libitum. Animal procedures were conducted according to standard ethical guidelines (European Communities Council Directive 86/ $609 / \mathrm{EEC}$ ) and approved by the local (Portuguese or Spanish) ethical committees. Rats were anesthetized with isoflurane before decapitation.

Cell culture. Human embryonic kidney 293T (HEK-293T) cells were grown in DMEM supplemented with $2 \mathrm{mM} \mathrm{L}$-glutamine, $100 \mu \mathrm{g} \cdot \mathrm{ml}^{-1}$ sodium pyruvate, $100 \mathrm{units} / \mathrm{ml}$ penicillin/streptomycin, and $5 \%(\mathrm{v} / \mathrm{v})$ heat-inactivated fetal bovine serum (FBS) (all supplements were from Invitrogen). Chinese hamster ovary (CHO) cells were cultured in MEM $\alpha$ medium without nucleosides supplemented with 100 units $/ \mathrm{ml}$ of penicillin/streptomycin and 10\% (v/v) heat-inactivated FBS. HEK-293T and $\mathrm{CHO}$ cells were maintained at $37^{\circ} \mathrm{C}$ in a humidified atmosphere of $5 \%$ $\mathrm{CO}_{2}$ and were passaged when they were $80-90 \%$ confluent, i.e., approximately twice a week.

Fusion proteins and expression vectors. The cDNAs for $\mathrm{D}_{1}, \mathrm{D}_{5}$, $\mathrm{Gal}_{1}, \mathrm{Gal}_{2}$, cannabinoid $\mathrm{CB}_{1}$, and serotonin $5 \mathrm{HT}_{2 \mathrm{~B}}$ receptors cloned into pcDNA3.1 were amplified without their stop codons using sense and antisense primers harboring unique EcoRI and BamHI sites to clone $\mathrm{D}_{1}$, $\mathrm{D}_{5}$, and $5 \mathrm{HT}_{2 \mathrm{~B}}$ receptors and EcoRV and $K p n \mathrm{I}$ sites to clone $\mathrm{Gal}_{2}$ receptors in the Renilla luciferase (Rluc) vector, or EcoRI and BamHI to clone $\mathrm{D}_{1}, \mathrm{D}_{5}$, and $\mathrm{CB}_{1}$ receptors and EcoRI and $K p n \mathrm{I}$ to clone the $\mathrm{Gal}_{1}$ receptor in the enhanced yellow fluorescent protein (EYFP) vector. The amplified fragments were subcloned to be in-frame into restriction sites of pcDNA3.1-Rluc (Renilla luciferase; Clontech) or pEYFP-N1 (Clontech) vectors resulting in the plasmids $D_{1}$-Rluc, $D_{1}-Y F P, D_{5}$-Rluc, $D_{5}-Y F P$, $\mathrm{Gal}_{1}$-YFP, and $\mathrm{Gal}_{2}$-Rluc. Expression of constructs was tested by confocal microscopy, and the receptor functionality by ERK1/2 phosphorylation (see Results). The cDNA encoding the $\mathrm{C}$ terminus of the rat $\mathrm{D}_{1}$ or $\mathrm{D}_{5}$ receptors $\left(\mathrm{D}_{1} \mathrm{CT}\right.$ and $\mathrm{D}_{5} \mathrm{CT}$, respectively) were amplified from Rat Brain QUICK-Clone cDNA (Clontech) by PCR using the following primers: D1-CT1012F (CAG AAG GCG TTC TCA ACC) and D1-CT1321R (AGT GGA ATG CTG TCC ACT) or $\mathrm{D}_{5}$-CT1051F (CCC ATC ATC TAT GCC
TTT AAT GCA GAC TTC) and $\mathrm{D}_{5}$-CT1425R (AGC AGT TTT ATC GAA ACA ATT GGG GGT GAG). The cDNA encoding $\mathrm{D}_{1} \mathrm{CT}$ or $\mathrm{D}_{5} \mathrm{CT}$ were subcloned into the BamHI/EcoRI sites of pGEX-4T-1 (GE Healthcare). A GST fusion protein containing the $\mathrm{C}$ terminus of the rat $\mathrm{D}_{1}$ or $\mathrm{D}_{5}$ receptors (GST- $\mathrm{D}_{1} \mathrm{CT}$ and GST- $\mathrm{D}_{5} \mathrm{CT}$, respectively) were generated corresponding to amino acid residues $227-335$ of the rat $D_{1}$ receptor and amino acid residues $358-475$ of the rat $\mathrm{D}_{5}$ receptor, respectively. Bacterial BL21 (DE3) cells with pGEX-4T-1/Drd5CT plasmid were grown overnight in imMedia medium (Invitrogen) using ampicillin selection. Protein production was induced with $0.5 \mathrm{~mm}$ isopropyl- $\beta$-Dthiogalactopyranoside (Sigma) at $20^{\circ} \mathrm{C}$ for $18 \mathrm{~h}$. Bacteria were harvested by centrifugation at $7,500 \times g$ for $15 \mathrm{~min}$ at $4^{\circ} \mathrm{C}$, and the pellet was suspended in cold PBS buffer with $1 \mathrm{~mm}$ PMSF and a protease inhibitor mixture (Roche). Cells were lysed by sonication, and the lysate was incubated for $1 \mathrm{~h}$ with $1 \%$ Triton X-100 and centrifuged at $18,000 \times g$ for 10 $\min$ at $4^{\circ} \mathrm{C}$. The supernatant was collected for purification of GST fusion protein. Purification of fusion proteins was performed using the Glutathione Sepharose 4B bead matrix (GE Healthcare) as described by the manufacturer.

Transient transfection and protein determination. HEK-293T or CHO cells growing in 35-mm-diameter wells of six-well plates were transiently transfected with the corresponding fusion protein cDNA by the ramified polyethylenimine (PEI; Sigma) method. Cells were incubated $(4 \mathrm{~h})$ with the corresponding cDNA together with ramified PEI $(5 \mathrm{ml} / \mathrm{mg}$ cDNA of $10 \mathrm{~mm} \mathrm{PEI}$ ) and $150 \mathrm{~mm} \mathrm{NaCl}$ in a serum-starved medium. After $4 \mathrm{~h}$, the medium was changed to a fresh complete culture medium. Forty-eight hours after transfection, cells were washed twice in quick succession in HBSS [containing the following (in $\mathrm{mm}$ ): $137 \mathrm{NaCl}, 5 \mathrm{KCl}, 0.34$ $\mathrm{Na}_{2} \mathrm{HPO}_{4} \times 12 \mathrm{H}_{2} \mathrm{O}, 0.44 \mathrm{KH}_{2} \mathrm{PO}_{4}, 1.26 \mathrm{CaCl}_{2} \times 2 \mathrm{H}_{2} \mathrm{O}, 0.4 \mathrm{MgSO}_{4} \times$ $7 \mathrm{H}_{2} \mathrm{O}, 0.5 \mathrm{MgCl}_{2}, 10$ HEPES, pH 7.4], supplemented with $0.1 \%$ glucose $(\mathrm{w} / \mathrm{v})$, detached by gently pipetting, and resuspended in the same buffer. To control the cell number, sample protein concentration was determined using a Bradford assay kit (Bio-Rad) using bovine serum albumin (BSA) dilutions as standards. HEK-293T cell suspension (20 $\mu \mathrm{g}$ of protein) was distributed into 96-well microplates; black plates with a transparent bottom (Porvair) were used for fluorescence determinations, whereas white opaque plates (Sigma) were used for bioluminescence resonance energy transfer (BRET) experiments.

BRET assays. HEK-293T cells were transiently cotransfected with the indicated amounts of plasmid cDNAs corresponding to the indicated fusion proteins (see corresponding figure legends). To quantify fluorescence proteins, cells ( $20 \mu \mathrm{g}$ protein) were distributed in 96-well microplates (black plates with a transparent bottom) and fluorescence was read in a Fluo Star Optima fluorimeter (BMG Lab Technologies) equipped with a high-energy xenon flash lamp, using a $10 \mathrm{~nm}$ bandwidth excitation filter at $400 \mathrm{~nm}$ reading. Receptor-fluorescence expression was determined as fluorescence of the sample minus the fluorescence of cells expressing receptor-Rluc alone. For BRET measurements, the equivalent of $20 \mu \mathrm{g}$ of cell suspension was distributed in 96-well microplates (Corning 3600, white plates; Sigma) and $5 \mu \mathrm{M}$ coelenterazine H (Invitrogen) was added. After $1 \mathrm{~min}$ of adding coelenterazine $\mathrm{H}$, readings were collected using a Mithras LB 940 (Berthold), which allows the integration of the signals detected in the short-wavelength filter at $485 \mathrm{~nm}(440-500 \mathrm{~nm})$ and the long-wavelength filter at $530 \mathrm{~nm}(510-590 \mathrm{~nm})$. To quantify receptor-Rluc expression, luminescence readings were performed after $10 \mathrm{~min}$ of adding $5 \mu \mathrm{M}$ coelenterazine $\mathrm{H}$. Cells expressing BRET donors alone were used to determine background. The net BRET is defined as [(long-wavelength emission)/(short-wavelength emission) $]-C f$, where $C f$ corresponds to [(long-wavelength emission)/(short-wavelength emission)] for the Rluc construct expressed alone in the same experiment. Curves were fitted using a nonlinear regression equation and assuming a single phase (GraphPad Prism software). BRET is expressed as mili BRET units (mBU: $1000 \times$ net BRET).

Immunocytochemistry. After $48 \mathrm{~h}$ of transfection, HEK-292T cells were fixed in 4\% paraformaldehyde for 15 min and washed with PBS containing $20 \mathrm{~mm}$ glycine (buffer A) to quench the aldehyde groups. Cells were permeabilized with buffer A containing $0.05 \%$ Triton X-100 for 5 min and then were treated with PBS containing $1 \%$ bovine serum albumin. After $1 \mathrm{~h}$ at room temperature, protein-Rluc was labeled with the primary 
mouse monoclonal anti-Rluc antibody (1/100; Millipore Bioscience Research Reagents) for $1 \mathrm{~h}$, washed, and stained with the secondary antibody Cy3 Donkey anti-mouse (1/200; Jackson ImmunoResearch). Protein-YFP was detected by its fluorescence properties. The slides were rinsed several times and mounted with a medium suitable for immunofluorescence (30\% Mowiol; Calbiochem). The samples were observed in a Leica SP2 confocal microscope (Leica Microsystems).

Pull-down assay. HEK-293T cells were collected after $48 \mathrm{~h}$ of transfection with $25 \mu \mathrm{g} \mathrm{Gal}_{1}$-YFP, Gal ${ }_{2}$-YFP, or pEYFP-N1 plasmid (control) and extracted in cell extraction buffer (10 mM Tris, $\mathrm{pH} 7.4,100 \mathrm{~mm} \mathrm{NaCl}$, 1 mm EDTA, 1 mm EGTA, 1 mm NaF, $20 \mathrm{~mm} \mathrm{Na}_{4} \mathrm{P}_{2} \mathrm{O}_{7}, 2 \mathrm{~mm} \mathrm{Na}_{3} \mathrm{VO}_{4}, 1 \%$ Triton X-100, $10 \%$ glycerol, $0.1 \%$ SDS, $0.5 \%$ deoxycholate) with $1 \mathrm{~mm}$ PMSF and a protease inhibitor mixture (Roche) for $30 \mathrm{~min}$ on ice. The cell extracts were centrifuged at $16,000 \times g$ for $10 \mathrm{~min}$ at $4^{\circ} \mathrm{C}$, and the supernatant was used for pull-down experiments. Pull-down experiments were performed by incubating cell extracts ( 135 relative fluorescence units per $800 \mu \mathrm{l}$ ) with $50 \mu \mathrm{g}$ GST-D ${ }_{1} \mathrm{CT}$, GST-D ${ }_{5} \mathrm{CT}$, or GST for $2 \mathrm{~h}$ with constant rotation at $4^{\circ} \mathrm{C}$. Then, $30 \mu \mathrm{l}$ Glutathione Sepharose $4 \mathrm{~B}$ beads were added, and incubation was prolonged for $1 \mathrm{~h}$. The beads were then washed four times with cold wash buffer (TBS, $0.1 \%$ Triton X-100, and protease inhibitor mixture). Subsequently, $50 \mu \mathrm{l}$ of elution buffer (10 mm reduced glutathione in $50 \mathrm{~mm}$ Tris- $\mathrm{HCl}, \mathrm{pH} 8.0$ ) was added to each sample and kept for $10 \mathrm{~min}$ at room temperature. Fluorescence in the eluted solution was measured with SpectraMax M5 microplate readers (Molecular Devices) using $514 \mathrm{~nm}$ wavelength excitation and $596 \mathrm{~nm}$ wavelength emission filters. Differences in relative fluorescence units among the different groups were statistically analyzed with repeatedmeasures ANOVA with Bonferroni's correction.

ERK phosphorylation assay. Transfected CHO cells were cultured in serum-free medium for $16 \mathrm{~h}$ before the addition of any agent. For assays in hippocampal slices, rat brains were rapidly removed and placed in ice-cold oxygenated $\left(95 \% \mathrm{O}_{2} / 5 \% \mathrm{CO}_{2}\right)$ Krebs- $\mathrm{HCO}_{3}^{-}$buffer [containing (in mM) $124 \mathrm{NaCl}, 4 \mathrm{KCl}, 1.25 \mathrm{NaH}_{2} \mathrm{PO}_{4}, 1.5 \mathrm{MgCl}_{2}, 1.5 \mathrm{CaCl}_{2}, 10$ glucose, and $26 \mathrm{NaHCO}_{3}, \mathrm{pH} 7.4$ ]. The brains were sliced perpendicularly to the long axis of the hippocampus at $4^{\circ} \mathrm{C}$. Slices ( $400 \mu \mathrm{m}$ thick) were kept at $4^{\circ} \mathrm{C}$ in Krebs- $\mathrm{HCO}_{3}^{-}$buffer during the dissection. Each hippocampal slice was transferred into an incubation tube containing 1 $\mathrm{ml}$ of ice-cold Krebs- $\mathrm{HCO}_{3}^{-}$buffer [containing (in mM) $124 \mathrm{NaCl}, 4 \mathrm{KCl}$, $1.25 \mathrm{NaH}_{2} \mathrm{PO}_{4}, 1.5 \mathrm{MgCl}_{2}, 1.5 \mathrm{CaCl}_{2}, 10$ glucose, and $26 \mathrm{NaHCO}_{3}$ ]. The temperature was raised to $23^{\circ} \mathrm{C}$, and after $30 \mathrm{~min}$ the medium was replaced by $2 \mathrm{ml}$ of fresh Krebs- $\mathrm{HCO}_{3}^{-}$buffer $\left(23^{\circ} \mathrm{C}\right)$ with similar composition. The slices were incubated under constant oxygenation $(95 \%$ $\mathrm{O}_{2} / 5 \% \mathrm{CO}_{2}$ ) at $30^{\circ} \mathrm{C}$ for $4-5 \mathrm{~h}$ in an Eppendorf-5 Prime Thermomixer. The medium was replaced by $200 \mu \mathrm{l}$ of fresh Krebs- $\mathrm{HCO}_{3}^{-}$buffer and incubated for $30 \mathrm{~min}$ before the addition of any agent. Cells or slices were treated or not with the indicated ligand for the indicated time and were rinsed with ice-cold PBS and lysed by the addition of $500 \mu \mathrm{l}$ of ice-cold lysis buffer (50 mм Tris-HCl, pH 7.4, $50 \mathrm{~mm} \mathrm{NaF,} 150 \mathrm{~mm} \mathrm{NaCl}, 45 \mathrm{~mm}$ $\beta$-glycerophosphate, $1 \%$ Triton X-100, $20 \mu \mathrm{M}$ phenyl-arsine oxide, 0.4 $\mathrm{mM} \mathrm{NaVO}_{4}$, and protease inhibitor mixture). The cellular debris was removed by centrifugation at $13,000 \times g$ for $5 \mathrm{~min}$ at $4^{\circ} \mathrm{C}$, and the protein was quantified by the bicinchoninic acid method using bovine serum albumin dilutions as standard. To determine the level of ERK1/2 phosphorylation, equivalent amounts of protein $(10 \mu \mathrm{g})$ were separated by electrophoresis on a denaturing 7.5\% SDS-polyacrylamide gel and transferred onto PVDF-fluorescence membranes. Odyssey blocking buffer (LI-COR Biosciences) was then added, and the membrane was rocked for $90 \mathrm{~min}$. The membranes were then probed with a mixture of a mouse anti-phospho-ERK1/2 antibody (1:2500; Sigma) and rabbit anti-ERK1/2 antibody that recognizes both phosphorylated and nonphosphorylated ERK1/2 (1:40,000; Sigma) for 2-3 h. Bands were visualized by the addition of a mixture of IRDye 800 (anti-mouse) antibody (1:10,000; Sigma) and IRDye 680 (anti-rabbit) antibody (1:10,000; Sigma) for $1 \mathrm{~h}$ and scanned by the Odyssey infrared scanner (LI-COR Biosciences). Bands densities were quantified using the scanner software exported to Excel (Microsoft). The level of phosphorylated ERK1/2 isoforms was normalized for differences in loading using the total ERK protein band intensities. Statistical differences between the different groups were analyzed by one-way ANOVA with Bonferroni's correction. $\left[{ }^{3} \mathrm{H}\right]$ Ach release from hippocampal synaptosomes. The synaptosomal fraction was prepared according to routine (Vaz et al., 2008). Briefly, after decapitation under halothane anesthesia, each brain was rapidly removed into ice-cold continuously oxygenated $\left(95 \% \mathrm{O}_{2} / 5 \% \mathrm{CO}_{2}\right)$ artificial CSF (aCSF) containing the following (in $\mathrm{mm}$ ): $124 \mathrm{NaCl}, 3 \mathrm{KCl}, 1.2$ $\mathrm{NaH}_{2} \mathrm{PO}_{4}, 25 \mathrm{NaHCO}_{3}, 2 \mathrm{CaCl}_{2}, 1 \mathrm{MgSO}_{4}$, and 10 glucose, $\mathrm{pH}$ 7.40. The whole hippocampus was dissected out free of the subiculum or enthorinal cortex areas and the ventral part, i.e., the portion lying in the temporal part of the brain, was isolated from the dorsal one (the portion lying just behind the septum) by a cut made perpendicularly to the long hippocampal axis. The ventral hippocampi were homogenized in an ice-cold isosmotic sucrose solution $(0.32 \mathrm{M}$, containing $1 \mathrm{~mm}$ EDTA, $1 \mathrm{mg} / \mathrm{ml}$ bovine serum albumin, and $10 \mathrm{~mm}$ HEPES, $\mathrm{pH}$ 7.4) and centrifuged at 3,000 $\times$ $g$ for $10 \mathrm{~min}$; the supernatant was centrifuged again at $14,000 \times g$ for 12 min. The whole procedure was conducted at $4^{\circ} \mathrm{C}$. The pellet was resuspended in $45 \%$ Percoll in Krebs-Henseleit-Ringer solution containing (in $\mathrm{mm}$ ) $140 \mathrm{NaCl}, 1$ EDTA, 10 HEPES, $5 \mathrm{KCl}$, and 5 glucose, and was centrifuged $14,000 \times g$ for $2 \mathrm{~min}$. The synaptosomal fraction corresponds to the top buoyant layer and was collected from the tube. Percoll was removed by two washes with a KHR solution; synaptosomes were then kept on ice and used within $3 \mathrm{~h}$. The synaptosomes were loaded for $20 \mathrm{~min}$ at $37^{\circ} \mathrm{C}$, with $\left[\right.$ methyl $\left.{ }^{3} \mathrm{H}\right]$ choline chloride $(10 \mu \mathrm{Ci} / \mathrm{ml}, 122 \mathrm{nM})$. Hemicholinium-3 $(10 \mu \mathrm{M})$ was present in all solutions up the end of the experiments to prevent choline uptake. Synaptosomes were then layered over Whatman GF/C filters and superfused (flow rate, $0.8 \mathrm{ml} / \mathrm{min}$; chamber volume, $90 \mu \mathrm{l}$ ) with gassed aCSF. After a $30 \mathrm{~min}$ washout period, the effluent was collected (release period) in $2 \mathrm{~min}$ fractions for $36 \mathrm{~min}$. The synaptosomes were stimulated during 2 min with $20 \mathrm{mM} \mathrm{K}^{+}$(isomolar substitution of $\mathrm{Na}^{+}$with $\mathrm{K}^{+}$in the perfusion buffer) at the 5 th and $23 \mathrm{rd}$ minutes after starting sample collection (S1 and S2, respectively). The tested drugs were added to the superfusion medium at the 17th minute, therefore before S2, and remained in the bath up to the end of the experiments. When we evaluated the changes of galanin effect by the $\mathrm{D}_{1}$-like receptor agonist SKF 38393, this was applied at the beginning of the washout period, and therefore it was present during $\mathrm{S} 1$ and $\mathrm{S} 2$ in both test and control chambers, whereas galanin was added before S2 in the test chambers. A "mirror" experiment was also performed to evaluate changes of the effect of SFK 38393 effect by galanin; in this case the neuropeptide was applied at the beginning of the washout period, being therefore present during S1 and S2 in both test and control chambers, whereas SKF 38393 was added before S2 in the test chambers. At the end of each experiment, aliquots $(500 \mu \mathrm{l})$ of each sample as well as the filters from each superfusion chamber were analyzed by liquid scintillation counting. The fractional release was expressed in terms of the percentage of total radioactivity present in the preparation at the beginning of the collection of each sample. The amount of radioactivity released by each pulse of $\mathrm{K}^{+}$(S1 and S2) was calculated by integration of the area of the peak after subtraction of the estimated basal tritium release. In each experiment, two synaptosome-loaded chambers were used as control chambers, the others being used as test chambers. In the test chambers, the test drug was added to the perfusion solution before S2, and the S2/S1 ratios in control and test conditions were calculated. The effect of the drug on the $\mathrm{K}^{+}$-evoked tritium release was expressed as percentage of change of the $\mathrm{S} 2 / \mathrm{S} 1$ ratios in test conditions compared to the $\mathrm{S} 2 / \mathrm{S} 1$ ratios in control conditions in the same experiments (i.e., with the same pool of synaptosomes). When present during S1 and S2, neither galanin nor SKF 38393 significantly ( $p>0.05$, Student's $t$ test) altered the S2/S1 ratio as compared with the S2/S1 ratio obtained in the absence of these drugs. The values presented are the mean \pm SEM of $n$ experiments. For comparisons, statistical significance was assessed with Student's $t$ test using GraphPad Software (Prism, version 4.02 for Windows).

Field EPSP recordings from hippocampal slices. After decapitation under halothane anesthesia, the hippocampus was dissected out of the brain on ice-cold continuously oxygenated $\left(95 \% \mathrm{O}_{2} / 5 \% \mathrm{CO}_{2}\right)$ aCSF as described above. Ventral and dorsal hippocampal slices ( $400 \mu \mathrm{m}$ thick, cut perpendicularly to the long axis of the hippocampus) were allowed to recover functionally and energetically for at least $1 \mathrm{~h}$ in a resting chamber filled with continuously oxygenated $\left(95 \% \mathrm{O}_{2} / 5 \% \mathrm{CO}_{2}\right)$ aCSF at room temperature $\left(22-25^{\circ} \mathrm{C}\right)$. After recovering, slices were transferred to a recording 
a
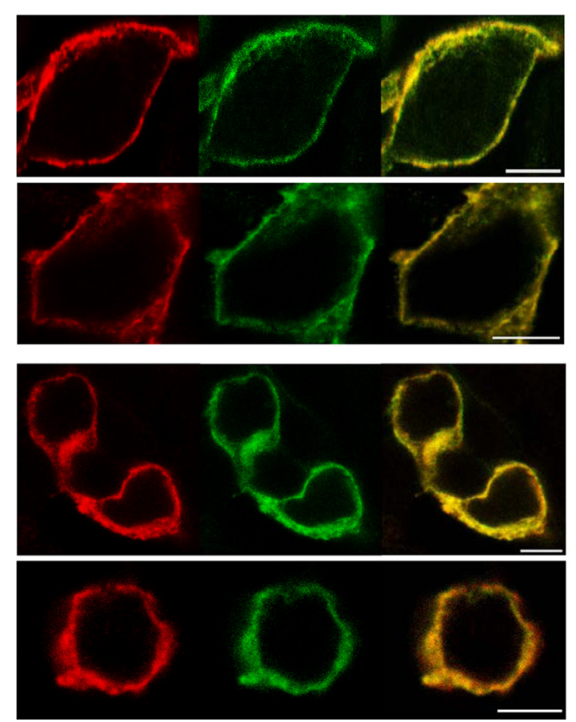

b

Coelenterazine
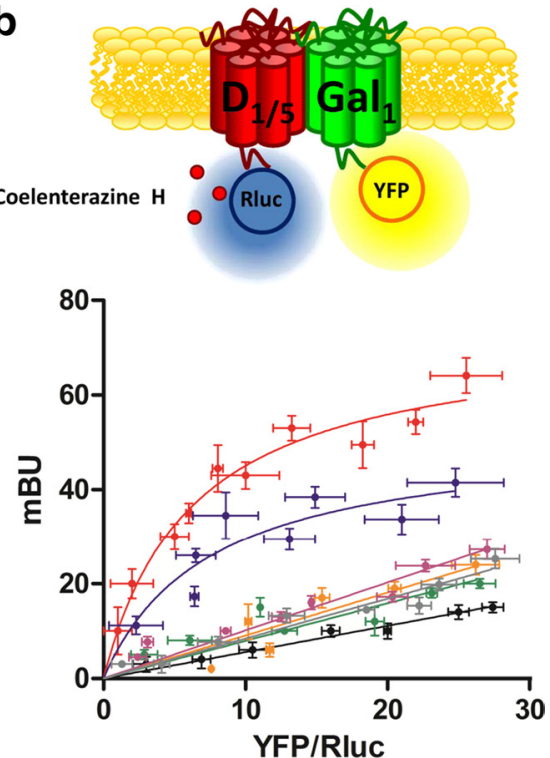

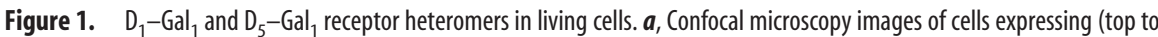
bottom) $D_{5}-$ Rluc $\left(0.6 \mu \mathrm{g}\right.$ plasmid) and Gal ${ }_{1}$-YFP ( $1 \mu \mathrm{g}$ plasmid $)$, Gal ${ }_{2}$-Rluc $\left(0.5 \mu \mathrm{g}\right.$ plasmid) and $\mathrm{D}_{5}$-YFP receptors $(1 \mu \mathrm{g}$ plasmid $)$, $\mathrm{D}_{1}$-Rluc (0.5 $\mu \mathrm{g}$ plasmid) and Gal ${ }_{1}$-YFP ( $1 \mu \mathrm{g}$ plasmid), and Gal ${ }_{2}$-Rluc ( $0.5 \mu \mathrm{g}$ plasmid) and $\mathrm{D}_{1}-$ YFP (1.3 $\mu \mathrm{g}$ plasmid) receptors. Proteins were identified by fluorescence or by immunocytochemistry. $D_{5}-$ Rluc, $D_{1}$-Rluc, or Gal ${ }_{2}$-Rluc receptor immunoreactivity is shown in red; Gal ${ }_{1}-Y F P, D_{5}-Y F P$, or $D_{1}-$ YFP receptor fluorescence in shown in green; and colocalization is shown in yellow. Scale bars, $5 \mu \mathrm{m} . \boldsymbol{b}$, BRET experiments were performed with cells coexpressing $\mathrm{D}_{5}$-Rluc ( $400 \mathrm{ng}$ plasmid; red) or $\mathrm{D}_{1}$-Rluc ( $300 \mathrm{ng}$ plasmid; blue) and Gal 1 -YFP receptors ( 0.4 to $7 \mu \mathrm{g}$ plasmid), Gal 2 -Rluc ( $300 \mathrm{ng}$ plasmid) and $\mathrm{D}_{5}$-YFP receptors ( 0.5 to $5 \mu \mathrm{g}$ plasmid; green) or $\mathrm{D}_{1}$-YFP receptors ( 0.5 to $4 \mu \mathrm{g}$ plasmid; purple), or, as negative controls, $\mathrm{D}_{5}$-Rluc ( $600 \mathrm{ng}$ plasmid; gray) or $\mathrm{D}_{1}$-Rluc (500 $\mathrm{ng}$ plasmid; orange) and $\mathrm{CB}_{1}$-YFP receptors ( 0.5 to $7 \mu \mathrm{g}$ plasmid) or $5 \mathrm{HT}_{2 \mathrm{~B}}$-Rluc (1 $\mu \mathrm{g}$ plasmid) and Gal ${ }_{1}$-YFP receptors ( 0.5 to $5 \mu \mathrm{g}$ plasmid) (black). Both fluorescence and luminescence of each sample were measured before every experiment to confirm similar donor expressions (about 150,000 luminescent units) while monitoring the increase acceptor expression (10,000 -70,000 fluorescent units). The relative amount of BRET is given as the ratio between the fluorescence of the acceptor minus the fluorescence detected in cells expressing only the donor and the luciferase activity of the donor. BRET data are expressed as the mean \pm SD of 4-16 different experiments grouped as a function of the amount of BRET acceptor. At the top, a scheme corresponding to a BRET assay is shown.

chamber ( $1 \mathrm{ml}$ plus $5 \mathrm{ml}$ dead volume) for submerged slices, and were continuously superfused $(3 \mathrm{ml} / \mathrm{min})$ at $32^{\circ} \mathrm{C}$ with oxygenated aCSF; the drugs were added to this superfusion solution. To minimize peptide lost resulting from binding to the perfusion system, all of the system was superfused with $0.1 \mathrm{mg} / \mathrm{ml}$ BSA before starting any experiment. Field EPSPs (fEPSPs) were recorded according to routine (Diógenes at al., $2004)$ through an extracellular microelectrode $(4 \mathrm{M} \mathrm{NaCl}, 2-6 \mathrm{M} \Omega$ resistance) placed in the stratum radiatum of the CA1 area. Stimulation (rectangular $0.1 \mathrm{~ms}$ pulses, once every $15 \mathrm{~s}$ ) was delivered through a concentric electrode placed on the Schaffer collateral-commissural fibbers in the stratum radiatum near the CA3-CA1 border. The intensity of stimulus $(80-200 \mu \mathrm{A})$ was initially adjusted to obtain a large fEPSP slope with a minimum population spike contamination. Recordings were obtained with an Axoclamp 2B amplifier and digitized (Molecular Devices). Individual responses were monitored, and averages of eight consecutive responses were continuously stored on a personal computer with the LTP program (Anderson and Collingridge, 2001). Data are expressed as the mean \pm SEM from $n$ number of slices. To allow comparisons between different experiments, slope values were normalized, taking as $100 \%$ of the averaged of the five values obtained immediately before applying the test compound. The significance of differences between the mean values obtained in test and control conditions was evaluated by Student's $t$ test. For multiple comparisons, the one-way ANOVA followed by the Bonferroni correction was used.

Drugs. Galanin was from Bachem. $(R)-(+)-7$-chloro-8-hydroxy-3methyl-1-phenyl-2,3,4,5-te trahydro- $1 \mathrm{H}$-3-benzazepine hydrochloride (SCH 23390), ( \pm )-6-chloro-2,3,4,5-tetrahydro-1-phenyl-1 H-3-benzazepine hydrobromide (SKF 81297), ( \pm )-1-phenyl-2,3,4,5-tetrahydro(1 H)-3-benzazepine-7,8-diol hydrobromide (SKF 38393), and galanin (1-13)-Pro-Pro-(Ala-Leu- $)_{2}$ Ala amide (M40) were from Tocris
Cookson. BSA and atropine were from Sigma. Galanin was supplied as a powder that was resuspended in TBS buffer (50 mM Tris-base, $150 \mathrm{~mm}$ $\mathrm{NaCl}, \mathrm{pH} 7.60)$ in a $0.5 \mathrm{~mm}$ concentration stock solution. SCH 23390 (10 mM), SKF 38393 (10 $\mathrm{mM})$, and atropine $(50 \mathrm{~mm})$ stock solutions were prepared in water. Aliquots of these stock solutions were kept frozen at $-20^{\circ} \mathrm{C}$ until use.

\section{Results}

$D_{1}$ and $D_{5}$ receptors form heteromers with $\mathrm{Gal}_{1}$ receptors but not with $\mathrm{Gal}_{2}$ receptors

We first looked for a molecular interaction between dopamine $\mathrm{D}_{1}$-like and $\mathrm{Gal}_{1}$ receptors using an in vitro energy transfer assay. First, receptors were cloned as fusion proteins competent for energy transfer experiments. To ensure the fusion proteins trafficked to the correct location in the cell, we performed immunofluorescence experiments in transfected HEK cells. All fusion proteins were found to properly express and localize at the plasma membrane (Fig. 1a). Fusion of Rluc or YFP did not modify receptor function, as determined by ERK1/2 phosphorylation assays (data not shown). Next, we examined whether $\mathrm{D}_{1}$ or $\mathrm{D}_{5}$ and $\mathrm{Gal}_{1}$ receptors form heteromers using the BRET technique. The BRET technique allows real-time detection of two proteins in close proximity in living cells. BRET measurements were performed in transiently cotransfected HEK cells using a constant amount of cDNA, corresponding to $\mathrm{D}_{1^{-}}$Rluc or $\mathrm{D}_{5}$-Rluc receptors, and increasing amounts of cDNA, corresponding to $\mathrm{Gal}_{1}$-YFP receptors. A positive and saturable BRET signal was obtained in cells coexpressing $\mathrm{D}_{1}$-Rluc and $\mathrm{Gal}_{1}$-YFP receptors, with a $\mathrm{BRET}_{\max }$ value of $47 \pm 4$ mBU and a BRET $T_{50}$ value of $7 \pm 2$, or in cells coexpressing $\mathrm{D}_{5^{-}}$ Rluc and $\mathrm{Gal}_{1}$-YFP receptors, with a $\mathrm{BRET}_{\max }$ value of $71 \pm 3$ $\mathrm{mBU}$ and $\mathrm{BRET}_{50}$ value of $6 \pm 1$ (Fig. $1 b$ ), indicating that both $D_{1}$ and $D_{5}$ receptors formed heteromers with $\mathrm{Gal}_{1}$ receptors. As negative controls we first used cells cotransfected with a constant amount of cDNA corresponding to $5 \mathrm{HT}_{2 \mathrm{~B}}$-Rluc and increasing amounts of cDNA corresponding to $\mathrm{Gal}_{1}$-YFP receptors. Second, we also used cells cotransfected with a constant amount of cDNA corresponding to $\mathrm{D}_{1}$-Rluc or $\mathrm{D}_{5}$-Rluc and increasing amounts of cDNA corresponding to $\mathrm{CB}_{1}$-YFP receptors. Only a small and linear BRET was detected (Fig. $1 b$ ), indicating that the saturable BRET between $\mathrm{D}_{1}$ or $\mathrm{D}_{5}$ and $\mathrm{Gal}_{1}$ represented a true complex.

Since $\mathrm{D}_{1}$-like and $\mathrm{Gal}_{1}$ receptors can form heteromers, we sought to determine whether $\mathrm{D}_{1}$-likeand $\mathrm{Gal}_{2}$ receptors could also form heteromers. Using confocal microscopy, we confirmed expression, proper trafficking of receptors, and colocalization between $\mathrm{D}_{1}$-YFP and $\mathrm{Gal}_{2}$-Rluc receptors and between $\mathrm{D}_{5}$-YFP and $\mathrm{Gal}_{2}$-Rluc receptors (Fig. $1 a$ ). When we performed BRET experiments, however, we obtained a linear nonspecific BRET signal in cells expressing a constant amount of $\mathrm{Gal}_{2}$-Rluc and increasing amounts of $\mathrm{D}_{1}$-YFP or $\mathrm{D}_{5}$-YFP receptors (Fig. $1 c$ ), suggesting that the two pairs of receptors are not able to form heteromers. Therefore, the results indicate that $\mathrm{D}_{1}$-like receptors 

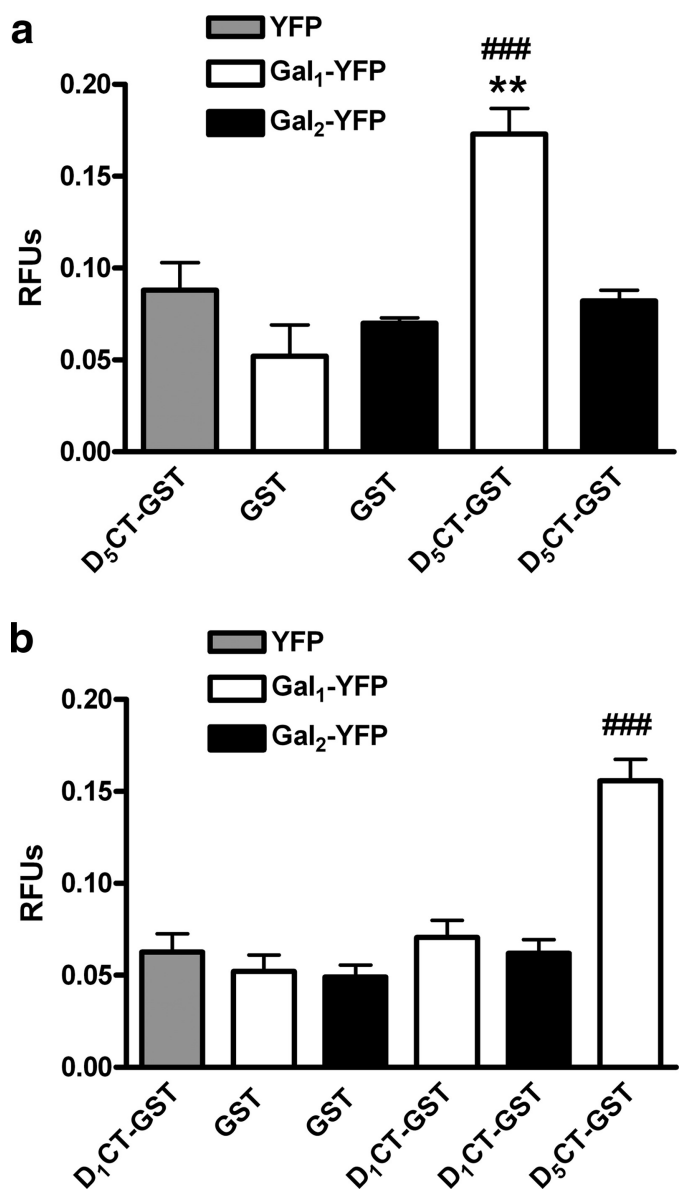

Figure 2. Role of the $C$-terminal domains of $D_{1}$ and $D_{5}$ receptors in heteromerization with $\mathrm{Gal}_{1}$ receptor. $\boldsymbol{a}, \boldsymbol{b}$, Extracts from cells transfected with either $\mathrm{Gal}_{1}-\mathrm{YFP}$ or Gal ${ }_{2}$-YFP receptors or just with YFP (see Materials and Methods) were incubated with GST-D D $_{5}$ T or with just GST (a) or GST- $D_{1} C T$, GST- $D_{5} C$, or with just GST (b). The results of pull-down experiments (see Materials and Methods) were analyzed by measuring fluorescence. Results are expressed as the mean \pm SEM (3 independent experiments with 3 replicates) of relative fluorescence units (RFUs); ${ }^{* *} p<$ 0.01 (significantly different compared to the pull down of YFP with GST-D $\left.\mathrm{D}_{5} \mathrm{CT}\right)$; ${ }^{\# \# \#} p<0.001$ (significantly different compared to the pull down of Gal1-YFP with GST; repeated-measures ANOVA with Bonferroni's correction).

show a preference for forming receptor heteromers with $\mathrm{Gal}_{1}$ receptors.

$D_{1}$ and $D_{5}$ receptors compete for the same molecular determinants of $\mathrm{Gal}_{1}$ receptors

Previous studies have shown that the $C$ termini of $D_{1}$ and $D_{5}$ receptors are selectively involved in the formation of heteromers with the ligand-gated ion channels of NMDA and $\mathrm{GABA}_{\mathrm{A}}$ receptors (Liu et al., 2000; Lee et al., 2002). We, therefore, reasoned that these same regions might interact with $\mathrm{Gal}_{1}$ receptors. We constructed plasmids expressing the C-terminal part of the $\mathrm{D}_{1}$ and $\mathrm{D}_{5}$ receptors fused to GST protein (GST-D $\mathrm{D}_{1} \mathrm{CT}$ and GST$\mathrm{D}_{5} \mathrm{CT}$, respectively). We produced this protein in Escherichia coli and then added it to lysates from HEK-293T cells transfected with either $\mathrm{Gal}_{1}$-YFP or $\mathrm{Gal}_{2}$-YFP receptors. Using Sepharose beads coated with glutathione, we precipitated GST-D ${ }_{5} \mathrm{CT}$. With analysis of fluorescence, we found that the GST-D ${ }_{5}$ CT fusion protein, but not GST alone, pulled down $\mathrm{Gal}_{1}$-YFP receptors, but not $\mathrm{Gal}_{2}$-YFP receptors, as demonstrated by a significant increase in fluorescence in the samples from cells expressing $\mathrm{Gal}_{1}$-YFP, compared with samples from cells expressing YFP alone (Fig. 2a).
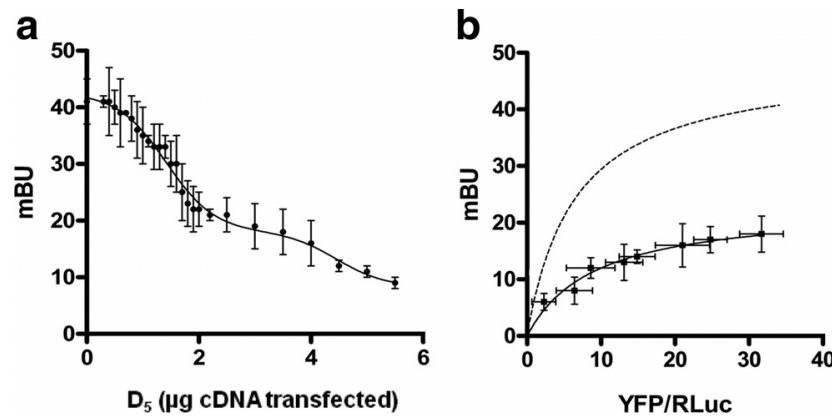

Figure 3. $D_{1}$ and $D_{5}$ receptors compete for binding to Gal ${ }_{1}$ receptors. $\boldsymbol{a}, \boldsymbol{b}$, BRET experiments were performed with cells coexpressing $D_{1}$-Rluc ( $300 \mathrm{ng}$ plasmid) and Gal ${ }_{1}-Y$ FP receptors $(4 \mu \mathrm{g}$ plasmid) and increasing amounts of $\mathrm{D}_{5}$ receptors ( 0 to $5.5 \mu \mathrm{g}$ plasmid) (a) or $\mathrm{D}_{1}$-Rluc ( $300 \mathrm{ng}$ plasmid), Gal ${ }_{1}$ YFP (0.3 to $5 \mu \mathrm{g}$ plasmid), and $\mathrm{D}_{5}$ receptors (1.5 $\mu \mathrm{g}$ plasmid) (b). In $\boldsymbol{a}$, no significant variation in luminescence caused by $D_{1}$-Rluc receptors (about 150,000 luminescent units) or fluorescence caused by Gal $1-$ YFP receptors (about 10,000-70,000 fluorescent units) was observed by increasing $D_{5}$ receptor expression. In $\boldsymbol{b}$, similar luminescence attributable to $D_{1}$-Rluc or fluorescence attributable to $\mathrm{Gal} \mathrm{l}_{1}$-YFP receptors was obtained in the absence or presence of $D_{5}$ receptors. The relative amount of $B R E T$ is given as the ratio between the fluorescence of the acceptor minus the fluorescence detected in cells expressing only the donor and the luciferase activity of the donor. BRET data are expressed as the mean \pm SD of 4-16 different experiments grouped as a function of the amount of BRET acceptor. The dashed curve represents BRET saturation curve obtained with the $D_{1}$-Rluc receptor and increasing amounts of CDNA for the Gal $1_{1}$ YFP receptor in the absence of $D_{5}$ receptors shown in Figure 1 .

When we tried the same experiments with GST-D $\mathrm{D}_{1} \mathrm{CT}$, we were unable to pull down $\mathrm{Gal}_{1}$-YFP or $\mathrm{Gal}_{2}$-YFP (Fig. $2 b$ ). In view of the very similar results obtained in BRET experiments with the selective heteromerization of both $D_{1}$ and $D_{5}$ receptors with $\mathrm{Gal}_{1}$ but not $\mathrm{Gal}_{2}$ receptors, these results suggest that additional regions outside of the $\mathrm{C}$ terminus play a role in forming heteromers and that there are differences between $D_{1}$ and $D_{5}$ receptors in the regions involved in heteromerization with $\mathrm{Gal}_{1}$ receptors. BRET competition experiments were then performed to determine whether $\mathrm{Gal}_{1}$ receptors use the same molecular determinants to heteromerize with D1 and D5 receptors. BRET was measured in cells coexpressing $\mathrm{D}_{1}$-Rluc and $\mathrm{Gal}_{1}$-YFP receptors (to give approximately BRET $\mathrm{max}_{\text {max }}$ values) with increasing amounts of $\mathrm{D}_{5}$ receptors. The BRET signal decreased to very low values in the presence of increasing amounts of $\mathrm{D}_{5}$ receptors, with a complex dose-response competition curve (Fig. $3 a$ ). Because the $\mathrm{D}_{1}-\mathrm{Gal}_{1}$ heteromer is disrupted by adding $\mathrm{D}_{5}$ receptor, $\mathrm{D}_{1}$ and $\mathrm{D}_{5}$ receptors must share a similar interaction surface on the $\mathrm{Gal}_{1}$ protein. To further support this hypothesis, a BRET saturation curve was performed in cells transfected with a constant amount of cDNA for the $\mathrm{D}_{1}$-Rluc receptor, with increasing amounts of $\mathrm{cDNA}$ for the $\mathrm{Gal}_{1}$-YFP receptor and with a constant amount of cDNA for $D_{5}$ receptors. Under these conditions, there was a very significant

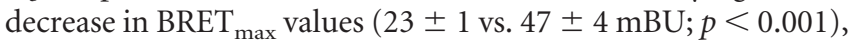
but not $\mathrm{BRET}_{50}$ values $(9 \pm 2$ vs. $7 \pm 2$ ), compared to the BRET saturation curve in the absence of $\mathrm{D}_{5}$ receptors (Fig. $3 b$ ), strongly suggesting that $\mathrm{D}_{1}$ and $\mathrm{D}_{5}$ receptors compete for the same region of $\mathrm{Gal}_{1}$ receptors.

\section{Functional characteristics of $\mathrm{D}_{1}-\mathrm{Gal}_{1}$ and $\mathrm{D}_{5}-\mathrm{Gal}_{1}$ receptor} heteromers

To investigate whether $\mathrm{D}_{1}$-like receptors can modify $\mathrm{Gal}_{1}$ receptor function, and vice versa, we measured changes in ERK1/2 phosphorylation in the presence or absence of $\mathrm{D}_{1}$-like and $\mathrm{Gal}_{1}$ receptor agonists and/or antagonists. First, the $\mathrm{D}_{1}$-like receptor agonist SKF 81297 (50 nM) time-dependently induced ERK1/2 phosphorylation in cells expressing $\mathrm{D}_{1}$ or $\mathrm{D}_{5}$ receptors, whereas 
a
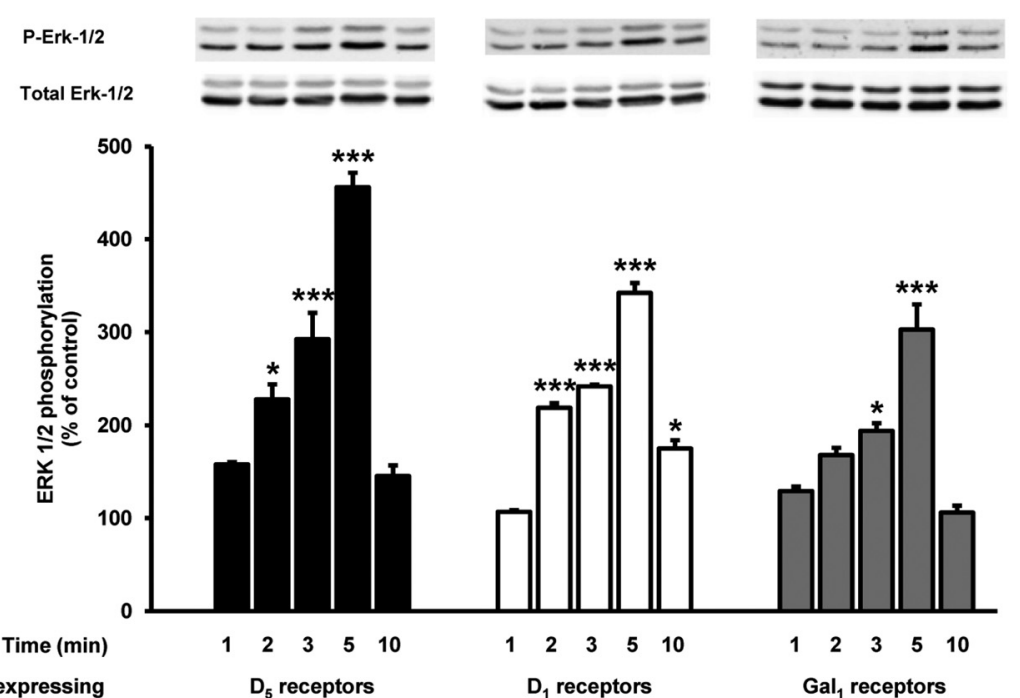

Cells expressing

b

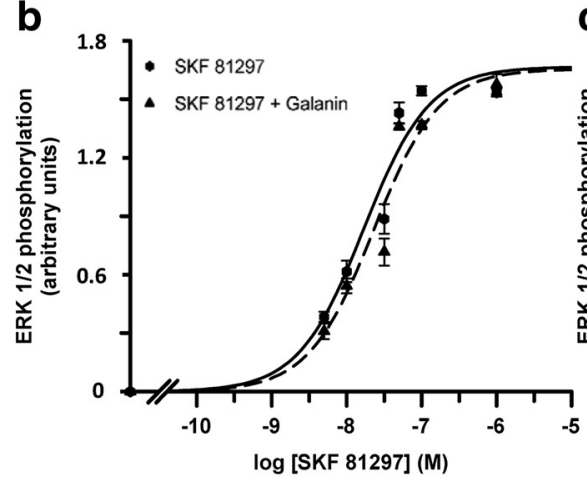

C
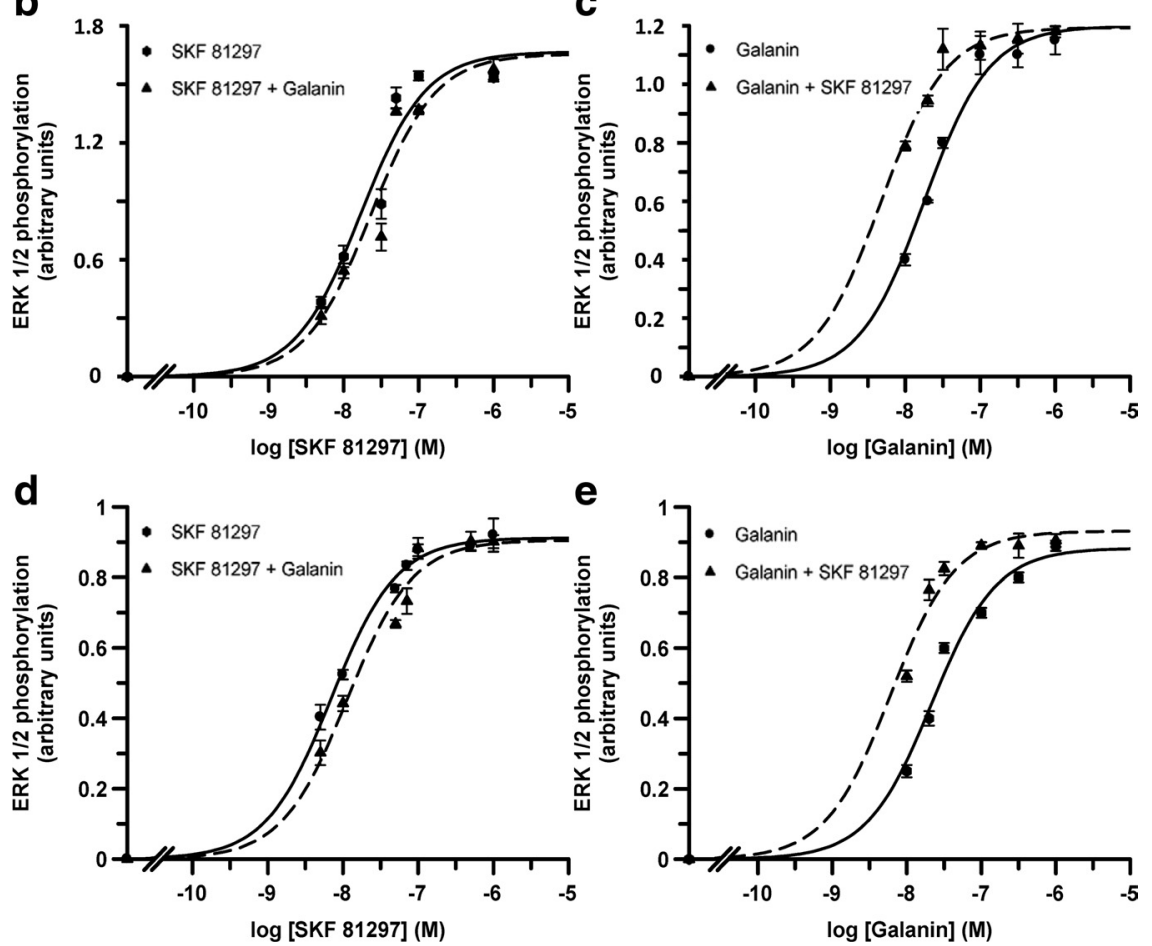

Figure 4. Cross talk between $D_{1}$-like receptors and Gal ${ }_{1}$ receptors on ERK1/2 phosphorylation in transfected cells. $\boldsymbol{a}$, Cells transfected with the cDNA corresponding to $D_{5}\left(1.5 \mu \mathrm{g}\right.$, black), $D_{1}\left(1.2 \mu \mathrm{g}\right.$, white), or Gal ${ }_{1}(2 \mu \mathrm{g}$, gray) receptors were stimulated for the indicated times with $50 \mathrm{~nm}$ (black) or $70 \mathrm{~nm}$ (white) of the $\mathrm{D}_{1}$-like receptor agonist SKF 81297 or with $100 \mathrm{~nm}$ galanin (gray). ERK1/2 phosphorylation was determined as indicated in Materials and Methods. The immunoreactive bands from three to five experiments were quantified and the values represent the mean $\pm S E M$ of the percentage of phosphorylation relative to the basal levels found in untreated cells; ${ }^{*} p<0.05$; ${ }^{* * *} p<0.001$ (significantly different compared to the results obtained after 1 min of agonist exposure; one-way ANOVA with Bonferroni's correction). $\boldsymbol{b}$ - $\boldsymbol{e}$, Cells cotransfected with the CDNA corresponding to $\mathrm{D}_{5}(1.3$ $\mu \mathrm{g})$ and $\mathrm{Gal}_{1}(1.8 \mu \mathrm{g})$ receptors $(\boldsymbol{b}, \boldsymbol{c})$ or $\mathrm{D}_{1}(1 \mu \mathrm{g})$ and $\mathrm{Gal}_{1}(1.8 \mu \mathrm{g})$ receptors $(\boldsymbol{d}, \boldsymbol{e})$ were treated for 5 min with the indicated concentrations of the $D_{1}$-like receptor agonist SKF 81297 in the absence (circles) or in the presence (triangles) of $100 \mathrm{~nm}$ galanin ( $\boldsymbol{b}$, d) or with the indicated concentrations of galanin in absence (circles) or presence (triangles) of $50 \mathrm{~nm}$ (c) or $70 \mathrm{~nm} \mathrm{SKF} 81297$ (d). The immunoreactive bands from four independent experiments were quantified and the values represent the mean \pm SEM of phosphorylation (arbitrary units) minus the basal levels found in SKF $81297-(\boldsymbol{b}, \boldsymbol{d})$ or galanin-untreated $(\boldsymbol{c}, \boldsymbol{e})$ cells. receptors were $17 \pm 2 \mathrm{~nm}$ and $23 \pm 3 \mathrm{~nm}$ in the absence and presence of galanin, respectively (nonpaired $t$ test, not significant; $n=5$ in both groups). In cells expressing both $\mathrm{D}_{1}$ and $\mathrm{Gal}_{1}$ receptors, $\mathrm{EC}_{50}$ values were $7 \pm 1 \mathrm{nM}$ and $11 \pm 1 \mathrm{nM}$ in the absence and presence of galanin, respectively (nonpaired $t$ test, not significant; $n=5$ in both groups). On the other hand, galanin-induced dose-response curves were significantly shifted to the left in the presence of SKF 81297 (50 nM) (Fig. $4 c, e) . \mathrm{EC}_{50}$ values were $17.1 \pm 0.7 \mathrm{nM}$ in the absence of SKF 81297 and $4.8 \pm 0.6$ $\mathrm{nM}$ in the presence of SKF 81297 in cells expressing both $\mathrm{D}_{5}$ and $\mathrm{Gal}_{1}$ receptors (nonpaired $t$ test, $p<0.001 ; n=4$ in both groups). $\mathrm{EC}_{50}$ values in cells expressing both $\mathrm{D}_{1}$ and $\mathrm{Gal}_{1}$ receptors were $21 \pm 2$ $\mathrm{nM}$ in the absence of SKF 81297 and $6 \pm 1$ $\mathrm{nM}$ in the presence of SKF 81297 (nonpaired $t$ test, $p<0.001 ; n=4$ in both groups). These results demonstrate that $\mathrm{D}_{1}$-like receptor agonist activation facilitates $\mathrm{Gal}_{1}$ receptor-mediated MAPK signaling, whereas the reverse is not true, since no significant functional effects were observed in the SKF 81297-induced doseresponse curves with galanin. Importantly, in cells expressing both $\mathrm{D}_{1}$ and $\mathrm{Gal}_{2}$ receptors or $\mathrm{D}_{5}$ and $\mathrm{Gal}_{2}$ receptors, galanin-induced dose-response curves were not significantly modified by the presence of SKF 81297 (Fig. 5), suggesting that the enhancement of $\mathrm{Gal}_{1}$ receptormediated MAPK signaling by $\mathrm{D}_{1}$-like receptor agonist activation is a biochemical property of $\mathrm{D}_{1}-\mathrm{Gal}_{1}$ and $\mathrm{D}_{5}-\mathrm{Gal}_{1}$ receptor heteromers.

Next, we examined the effect of heteromer formation on antagonist-modulation of agonist-induced ERK1/2 phosphorylation. The $\mathrm{D}_{1}$-like receptor antagonist $\mathrm{SCH}$ $23390(10 \mu \mathrm{M})$ was able to block ERK1/2 phosphorylation caused by SKF 81297 in cells expressing $D_{1}$ or $D_{5}$ receptors, whereas the putative nonselective galanin receptor antagonist M40 $(10 \mu \mathrm{M})$ blocked galanin-induced ERK1/2 phosphorylation in cells expressing $\mathrm{Gal}_{1}$ receptors (Fig. $6 a$ ). It is important to mention that M40, as well as other galanin-like peptides, has been shown to act as full agonists in some cell lines, although they are clearly antagonists in vivo (Lang et al., 2007). In our hands, M40 behaved as a galanin receptor antagonist, as evidenced by the complete galanin (100 nM) time-dependently induced ERK1/2 phosphorylation in cells expressing $\mathrm{Gal}_{1}$ receptors (Fig. 4a). In cells expressing both $\mathrm{D}_{5}$ and $\mathrm{Gal}_{1}$ receptors (Fig. $4 b, c$ ) or $\mathrm{D}_{1}$ and $\mathrm{Gal}_{1}$ (Fig. 4d,e) receptors, SKF 81297-induced dose-response curves were not significantly modified by the presence of galanin (100 $\mathrm{nM}$ ) (Fig. $4 b, d) . \mathrm{EC}_{50}$ values in cells expressing both $\mathrm{D}_{5}$ and $\mathrm{Gal}_{1}$ reversion of galanin-induced signaling. In addition, we established that in cells expressing only $\mathrm{D}_{1}$ or $\mathrm{D}_{5}$ receptors, signaling induced by the $\mathrm{D}_{1}$-like receptor agonist SKF 81297 was not modified by the presence of M40, and in cells expressing only $\mathrm{Gal}_{1}$, signaling induced by galanin was not altered by addition of $\mathrm{SCH}$ 23390 (Fig. 6a). In cells coexpressing both $\mathrm{D}_{5}$ and $\mathrm{Gal}_{1}$ receptors 
(Fig. $6 b$ ) or both $\mathrm{D}_{1}$ and $\mathrm{Gal}_{1}$ receptors (Fig. $6 c$ ), $\mathrm{D}_{1}$-like receptor-mediated ERK1/2 phosphorylation could be blocked by SCH 23390 but not by M40. However, galanin-induced ERK1/2 phosphorylation was counteracted by both M40 and SCH 23390 (Fig. 6b,c). This is a clear example of unidirectional crossantagonism in a receptor heteromer (Carriba et al., 2007; Ferrada et al., 2009; Navarro et al., 2010). Since, by definition, an antagonist is not able to induce intracellular signaling, the more straightforward way to explain the effect of $D_{1}$-like receptor antagonist on $\mathrm{Gal}_{1}$ receptor activation is through a direct proteinprotein interaction between both receptors.

\section{$\mathrm{D}_{1}$-like-Gal ${ }_{1}$ receptor heteromers are expressed in the rat ventral hippocampus}

In view of the cross-antagonism clearly observed in the transfected cells, we decided to use a similar approach to seek biochemical evidence ("biochemical fingerprint") for the existence of $\mathrm{D}_{1}$-like- $\mathrm{Gal}_{1}$ receptor heteromers in the brain (Ferré et al., 2009). Therefore, to test whether $\mathrm{D}_{1}-\mathrm{Gal}_{1}$ or $\mathrm{D}_{5}-$ $\mathrm{Gal}_{1}$ receptor heteromers exist in the brain, we isolated rat ventral and dorsal hippocampal slices and compared the ability of the $\mathrm{D}_{1}$-like receptor antagonist SCH 23390 to block the effect of galanin on ERK1/2 phosphorylation. Slices were incubated with galanin in the absence or in the presence of either SCH 23390 or the galanin receptor antagonist M40. In the ventral hippocampus, the results reproduced the cross-antagonism found in transfected cells (Fig. 7). ERK1/2 phosphorylation induced by gala$\operatorname{nin}(300 \mathrm{nM})$ was not blocked only by M40 $(10 \mu \mathrm{M})$, but also by SCH23390 (10 $\mu \mathrm{M})$. In contrast, in dorsal hippocampus slices, SCH23390 $(10 \mu \mathrm{M})$ failed to antagonize the effect of galanin (Fig. 7). These results provide strong evidence for the existence of $\mathrm{D}_{1}$ like- $\mathrm{Gal}_{1}$ receptor heteromers in the ventral hippocampus.

The role of $\mathrm{D}_{1}$-like and $\mathrm{Gal}_{1}$ receptor coactivation on $\mathrm{K}^{+}$-induced $\left[{ }^{3} \mathrm{H}\right] \mathrm{ACh}$ release in synaptosomes from rat ventral hippocampus

Having established that $\mathrm{D}_{1}$-like-Gal ${ }_{1}$ receptor heteromers occur in the ventral hippocampus, we looked for their functional role by first analyzing the effect of a $\mathrm{D}_{1}$-like agonist and galanin on $\mathrm{K}^{+}$-induced $\left[{ }^{3} \mathrm{H}\right] \mathrm{ACh}$ release in isolated synaptosomes from rat ventral hippocampus. The $\mathrm{D}_{1}$-like receptor agonists SKF 81297 and SKF 38393 have a similar affinity for $D_{1}$ and $D_{5}$ receptors. The major difference between the two agonists is a significantly higher selectivity for $\mathrm{D}_{1}$ versus dopamine $\mathrm{D}_{2}$ receptors and $\mathrm{D}_{1}$ versus serotonin $5-\mathrm{HT}_{2 \mathrm{~A}}$ receptors of SKF 38393 in untreated cells (100\%).
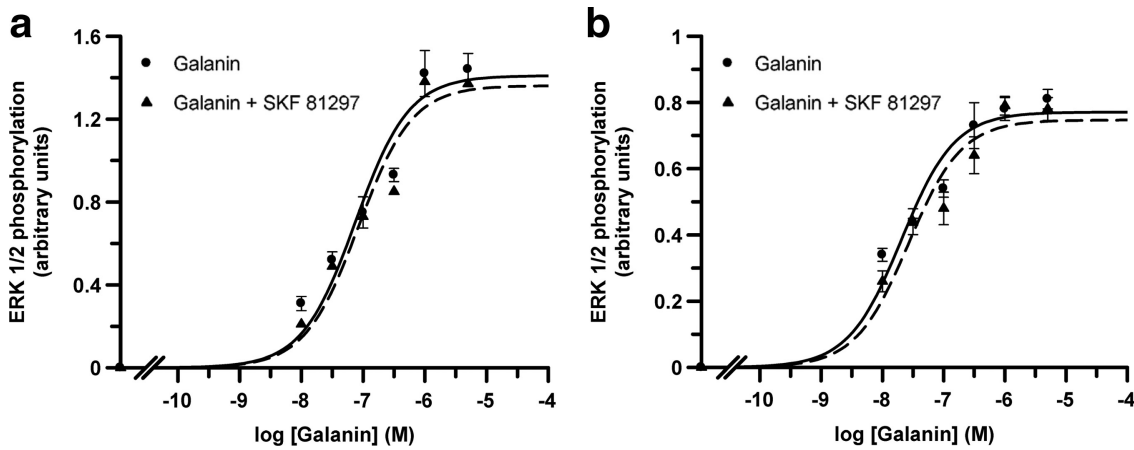

Figure 5. Lack of cross talk between $D_{1}$-like receptors and Gal 2 receptors on ERK1/2 phosphorylation in transfected cells. $\boldsymbol{a}, \boldsymbol{b}$, Cells were cotransfected with the CDNA corresponding to $D_{5}(1.5 \mu \mathrm{g})$ and Gal $2(2 \mu \mathrm{g})$ receptors $(\boldsymbol{a})$ or to $\mathrm{D}_{1}(1 \mu \mathrm{g})$ and Gal $2(2 \mu \mathrm{g})$ receptors $(\boldsymbol{b})$. Cells were treated for 5 min with the indicated concentrations of galanin in the absence (circles) or in the presence (triangles) of $50 \mathrm{~nm}(\boldsymbol{a})$ or $70 \mathrm{~nm}(\boldsymbol{b})$ of SKF 81297 . The immunoreactive bands from four independent experiments were quantified and the values represent the mean \pm SEM of phosphorylation (arbitrary units) minus the basal levels found in untreated cells.
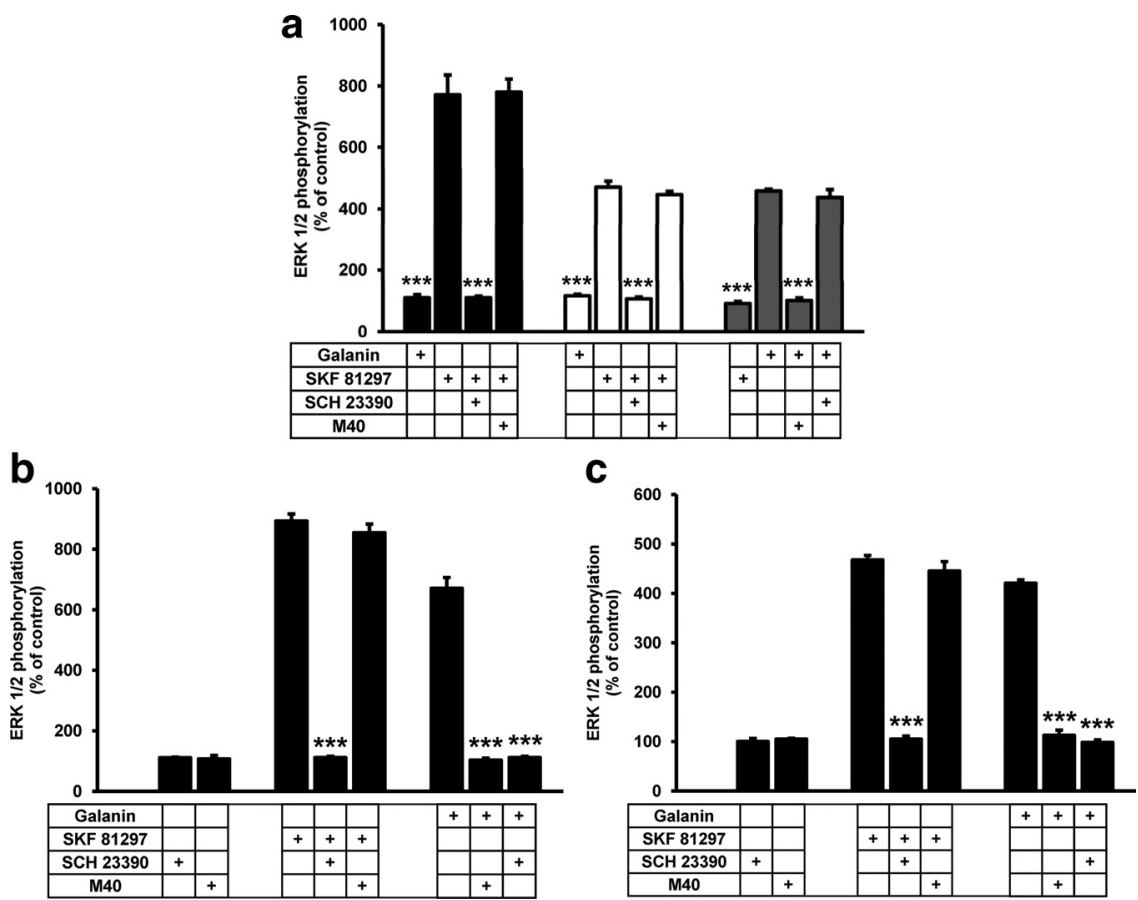

Figure 6. $\quad D_{1}$-like receptor antagonist-mediated blockade of galanin-induced ERK1/2 phosphorylation in cells expressing $D_{1}$ like and $\mathrm{Gal}_{1}$ receptors. $\boldsymbol{a}$, Cells were transfected with the cDNA corresponding to $\mathrm{D}_{5}\left(1.5 \mu \mathrm{g}\right.$, black), $\mathrm{D}_{1}(1.2 \mu \mathrm{g}$, white) or Gal receptors ( $2 \mu \mathrm{g}$, gray) and were stimulated with the $D_{1}$-like receptor agonist SKF 81297 (70 nm) or with galanin (100 nm) in the presence or absence of the $\mathrm{D}_{1}$-like receptor antagonist SCH $23390(10 \mu \mathrm{M})$ or the Gal ${ }_{1}$ receptor antagonist $\mathrm{M} 40(10 \mu \mathrm{M})$; ${ }^{* * *} p<$ 0.001 [significantly different compared to the effect of SKF 81297 alone (black and white columns) or to the effect of galanin alone (gray columns); one-way ANOVA with Bonferroni's correction]. $\boldsymbol{b}, \boldsymbol{c}$, Cells cotransfected with the CDNA corresponding to $\mathrm{D}_{5}(1.3 \mu \mathrm{g})$ and $\mathrm{Gal}_{1}$ receptors $(1.8 \mu \mathrm{g})(\boldsymbol{b})$ or to $\mathrm{D}_{1}(1 \mu \mathrm{g})$ and Gal $\mathrm{l}_{1}(1.8 \mu \mathrm{g})$ receptors $(\boldsymbol{c})$ were treated with $\mathrm{SCH} 23390(10 \mu \mathrm{m}), \mathrm{M} 40(10 \mu \mathrm{M})$, SKF $81297(70 \mathrm{~nm})$, or galanin $(100 \mathrm{~nm})$ alone or in combination; ${ }^{* * *} p<0.001$ [significantly different compared to the effect of SKF 81297 alone (in cells treated with SKF 81297) or to the effect of galanin alone (in cells treated with galanin); one-way ANOVA with Bonferroni's correction]. In all cases, cells were treated for $5 \mathrm{~min}$ with the indicated concentrations of agonists and 20 min before the addition of agonists with the indicated concentrations of antagonists. The inmunoreactive bands from four to five experiments were quantified, and the values represent the mean \pm SEM of the percentage of phosphorylation relative to the basal levels found

compared to SKF 81297 (Seeman and Van Tol, 1994; Neumeyer et al., 2003). Since selectivity was a major concern when dealing with hippocampal tissue, we decided to shift to SKF 38393 as the $\mathrm{D}_{1}$-like receptor agonist in the studies of ACh release in synaptosomes and the electrophysiological studies in slices. Neither galanin, at low nanomolar concentrations (30-100 nM) in the range used by Wang et al. (1999) in rat cortical slices and cortical syn- 


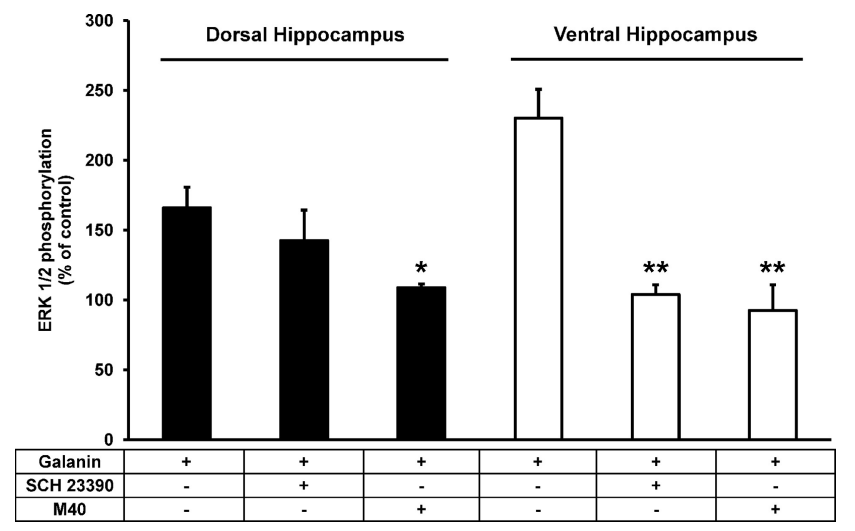

Figure 7. $\quad D_{1}$-like receptor antagonist-mediated blockade of galanin-induced ERK1/2 phosphorylation in rat hippocampal slices. Slices from dorsal (black) or ventral (white) hippocampus were treated for 10 min with medium, SCH $23390(10 \mu \mathrm{m})$, or M40 (10 $\mu \mathrm{m})$ before the addition of galanin ( $300 \mathrm{~nm}$ ) and an additional incubation period of $10 \mathrm{~min}$. The inmunoreactive bands from four slices from two different animals were quantified and the values represent the mean \pm SEM of the percentage of phosphorylation relative to the basal levels found in untreated slices (100\%). ${ }^{*} p<0.05 ;{ }^{* *} p<0.01$ (significantly different compared to the effect of galanin alone; one-way ANOVA with Bonferroni's correction).
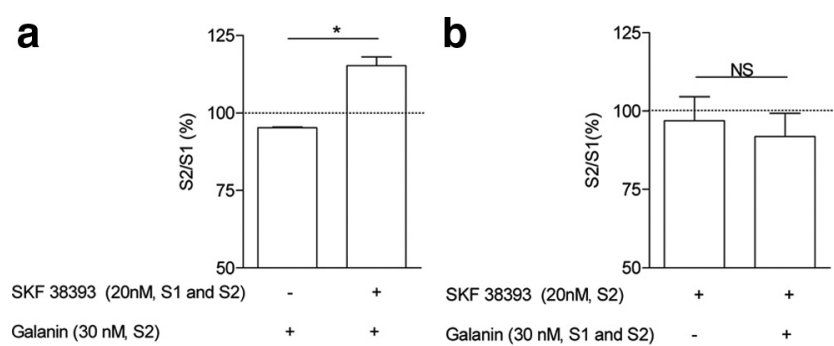

Figure 8. Effect of a $\mathrm{D}_{1}$-like receptor agonist and galanin on $\mathrm{K}^{+}$-induced $\left[{ }^{3} \mathrm{H}\right] \mathrm{ACh}$ release from ventral hippocampal synaptosomes. $\boldsymbol{a}$, Dopamine receptors were activated (right column) by preincubation with the agonist SKF 38393 before addition of galanin. $\boldsymbol{b}$, Galanin receptors were activated (right column) by preincubation with galanin before addition of SKF 38393 . Ordinates represent the $S 2 / S 1$ ratios as percentage of the control value in the same experiments (see Materials and Methods). Drug conditions during S1 and $S 2$ are indicated below each bar. In the ordinates, $100 \%$ represents the $\$ 2 / S 1$ ratio in the absence of the test drug, i.e., in the absence of galanin ( $\boldsymbol{a}$ ) or in the absence of SKF $38393(\boldsymbol{b})$, using the same synaptosomal batch. An S2/S1 ratio close to $100 \%$ represents, therefore, absence of effect of the test drug (galanin in $\boldsymbol{a}$ or SKF 38393 in $\boldsymbol{b})$. Values are mean \pm SEM $(n=3-6)$. In $\boldsymbol{a}, 100 \%$ corresponds to $0.76 \pm$ 0.046 , and in $\boldsymbol{b}$ it corresponds to $0.70 \pm 0.029$. The presence of SKF 38393 (a) or of galanin $(\boldsymbol{b})$ during $S 1$ and $S 2$ did not significantly affect $S 2 / S 1$ ratios compared with those obtained in the absence of any drug. ${ }^{*} p<0.05 ;$ NS, $p>0.05$ (Student's $t$ test).

aptosomal preparations, nor the $\mathrm{D}_{1}$-like receptor agonist SKF $38393(20-100 \mathrm{nM})$ significantly $(p>0.05 ; n=3-6)$ affected $\mathrm{K}^{+}$-induced ACh release, as assessed by modifications of the S2/S1 ratio after addition of the agonists before S2. However, prior addition of SKF 38393 (20 nM; added before S1 and being present during S1 and S2) triggered an excitatory effect $(p<0.05$; $n=6$ ) of galanin (30 nM; only added before S2) on evoked ACh release (Fig. 8a). On the other hand, no significant functional effects where observed with the reverse protocol, since adding galanin ( $30 \mathrm{~nm}$ ) before S1 did not influence the absence of effect of SKF 38393 (20 nM, only added before S2) (Fig. 8b). These results nicely correlate with the functional results obtained in cells expressing $\mathrm{D}_{1}$ or $\mathrm{D}_{5}$ and $\mathrm{Gal}_{1}$ receptors, showing the selective enhancement of $\mathrm{Gal}_{1}$ but not $\mathrm{Gal}_{2}$ receptor-mediated MAPK signaling by a $\mathrm{D}_{1}$-like receptor agonist. Therefore, the results strongly suggest that $\mathrm{D}_{1}-\mathrm{Gal}_{1}$ or $\mathrm{D}_{5}-\mathrm{Gal}_{1}$ receptor heteromers are present in ventral hippocampal cholinergic terminals where they modulate ACh release.

\section{The role of $\mathrm{D}_{1}$-like and $\mathrm{Gal}_{1}$ receptor coactivation on rat ventral hippocampus synaptic transmission}

To identify whether $\mathrm{D}_{1}$-like- $\mathrm{Gal}_{1}$ receptor interactions affect excitatory synaptic transmission in the hippocampus, we evaluated the effect of galanin on EPSPs in hippocampal slices (Fig. 9a) in the absence or presence of the dopaminergic receptor agonist SKF 38393. As illustrated in Figure 9, $b$ and $e$, when galanin (30 $\mathrm{nM}$ ) was applied alone to ventral hippocampal slices, there was a statistically significant $(p<0.05 ; n=9)$ inhibition $(21 \pm 2.6 \%)$ of the slope of fEPSP. On the other hand, SKF 38393 (20 nM) was virtually devoid of effect $(n=7)$ on the slope of fEPSP (Fig. $9 c, e$ ). However, in the presence of SKF 38393, the effect of galanin was reversed and it produced a significant increase of $15.4 \pm 2.4 \%$ $(p<0.05 ; n=8)$ in the slope of fEPSPs (Fig. $9 d, f)$. These results indicate a synergistic effect when both $\mathrm{D}_{1}$-like and $\mathrm{Gal}_{1}$ receptors are costimulated by agonists and match those results obtained in synaptosomal preparations when measuring ACh release and those results obtained in transfected cells and in ventral hippocampal slices while measuring EPK phosphorylation. Moreover, blockade of $\mathrm{D}_{1}$-like receptors with SCH 23390 ( $1 \mu \mathrm{M}$; added 30 min before SKF 38393) completely counteracted the effect of SKF 38393 (Fig. 9d,f). Indeed, in the presence of SCH 23390 (1 $\mu \mathrm{M})$ and SKF 38393 (20 nM), galanin (30 nM) decreased $(p<0.05$; $n=6$ ) the slope of fEPSPs by $21.2 \pm 3.4 \%$ (Fig. $9 d$ ), an effect similar to that observed when galanin was applied to the slices alone (Fig. 9b,f).

Based on our results on the modulation of ACh release from isolated nerve terminals (see Fig. 8) and previous evidence that dopamine and galanin receptors regulate septohippocampal cholinergic neurotransmission, we hypothesized that the cross talk between galanin and dopamine receptors involved in the modulation of hippocampal excitatory transmission resulted from modulation of cholinergic neurotransmission. To test this hypothesis, we used the muscarinic cholinergic receptor antagonist atropine $(5 \mu \mathrm{M})$, which by itself did not significantly modify fEPSP when applied to ventral hippocampal slices (Fig. 10b). The application of SKF 38393 (20 nM) after previous application (at least $30 \mathrm{~min}$ before) of atropine also did not significantly affect synaptic transmission (Fig. 10b). However, when galanin was added, a significant inhibition $(p<0.05 ; n=6)$ of the slope of fEPSP was observed (Fig. 10a,b). This inhibition $(21 \pm 5 \%)$ was similar to the inhibition obtained when galanin was applied in the absence of any drug $(18 \pm 0.9 \%)$ (Fig. $8 a, d)$, demonstrating a cholinergic-independent depressant effect of galanin, but a cholinergic-dependent facilitatory action of galanin that requires $\mathrm{D}_{1}$-like receptor activation. These results suggest that $\mathrm{D}_{1}$-like$\mathrm{Gal}_{1}$ receptor heteromers localized in cholinergic terminals influence excitatory synaptic transmission in the ventral hippocampus. Finally, we performed fEPSP measurements using slices of dorsal hippocampus. Application of galanin (30 nM) to dorsal hippocampal slices had no significant effect on fEPSP slope (Fig. 11a). Application of SKF 38393 (20 nM) was also devoid of any effect on fEPSP slope (Fig. 11b). Furthermore, previous addition of SKF 38393 (20 $\mathrm{nM} ; 30 \mathrm{~min}$ before) did not trigger any effect of galanin on fEPSPs (Fig. $11 c, d$ ). These results agree with the selective existence of $\mathrm{D}_{1}$ like- $\mathrm{Gal}_{1}$ receptor interactions in the ventral versus the dorsal hippocampus, as indicated by the ERK1/2 phosphorylation experiments in hippocampal slices. 


\section{Discussion}

By using a multidisciplinary approach, we provide several important mechanistic and functional insights into the role of galanin and dopamine on regulation of ACh release in the hippocampus. We show, for the first time, that dopamine $\mathrm{D}_{1}$-like receptors form heteromers with $\mathrm{Gal}_{1}$ but not $\mathrm{Gal}_{2}$ receptors in transfected cells and in rat ventral hippocampus. Within the $\mathrm{D}_{1}-\mathrm{Gal}_{1}$ and $\mathrm{D}_{5}-\mathrm{Gal}_{1}$ receptor heteromers, dopamine receptor activation and blockade potentiate and counteract, respectively, MAPK activation induced by stimulation of $\mathrm{Gal}_{1}$ receptors, whereas $\mathrm{Gal}_{1}$ receptor ligands do not modify $\mathrm{D}_{1}$-like receptor-mediated MAPK activation. We also demonstrate that dopamine and galanin work in concert to modulate cholinergic neurotransmission in the ventral hippocampus and that this modulation could occur via heteromers between $\mathrm{D}_{1}$ or $\mathrm{D}_{5}$ receptors and $\mathrm{Gal}_{1}$ receptors.

Using an in vitro cell culture system, we demonstrated by BRET the ability of both $D_{1}$ and $D_{5}$ receptors to form heteromers with $\mathrm{Gal}_{1}$ but not $\mathrm{Gal}_{2}$ receptors. This is not surprising if we consider that these two galanin receptors have relatively low amino acid similarity (Branchek et al., 2000). Although both $D_{1}$ and $D_{5}$ receptors were able to compete for their heteromerization with the $\mathrm{Gal}_{1}$ receptor, only the $\mathrm{C}$ terminus of the $\mathrm{D}_{5}$ receptor pulled down the whole $\mathrm{Gal}_{1}$ receptor from membrane preparations of transfected cells. On the one hand, these results suggest that additional regions outside of the $\mathrm{C}$ terminus play a role in forming heteromers and that there are differences between $D_{5}$ and $D_{1}$ receptors in the regions involved in heteromerization with $\mathrm{Gal}_{1}$ receptors. On the other hand, our results strongly suggest that $\mathrm{D}_{1}$ and $\mathrm{D}_{5}$ receptors compete for the same region of $\mathrm{Gal}_{1}$ receptors.

One of the main challenges in the study of membrane protein complexes is their identification in native tissues. Solubility issues and unreliable antibodies make coimmunoprecipitation experiments difficult to interpret, and current spectroscopic approaches, with few exceptions, lack the resolution for an in situ approach at the single-molecule level. These limitations thus require indirect approaches to validate the presence of such membrane complexes, such as the determination of a biochemical property of the receptor heteromer, which can be used as a "biochemical fingerprint" (Ferré et al., 2009). The cross-antagonism in which a $D_{1}$-like receptor antagonist is able to block the effect of a $\mathrm{Gal}_{1}$ receptor agonist is very difficult to explain by a mechanism not involving receptor heteromerization, taking into account that an antagonist does not induce intracellular signaling. This d Without $\mathrm{SCH} 23390(1 \mu \mathrm{M})$

- With $\mathrm{SCH} 23390(1 \mu \mathrm{M})$

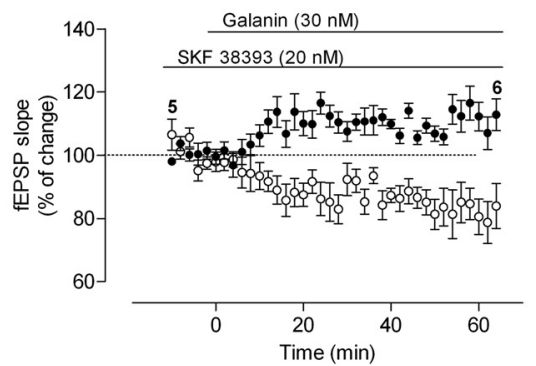

e

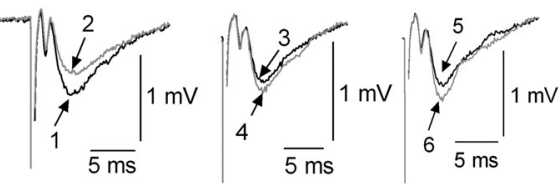

f

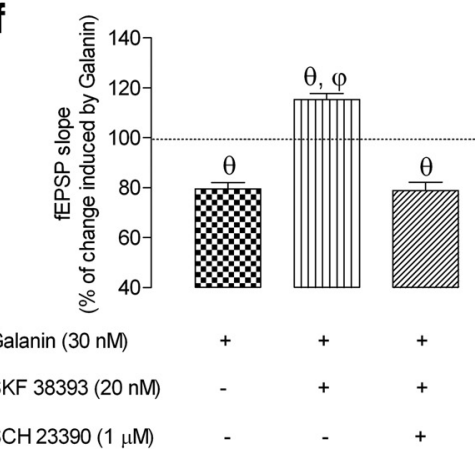

Figure 9. Effect of coactivation of $\mathrm{D}_{1}$-like and galanin receptors on galanin-mediated modulation of synaptic transmission in the ventral hippocampus. $\boldsymbol{a}$, Schematic representation of a transverse hippocampal slice with the electrode configuration used to record fEPSPs in the CA1 apical dendritic layer (stratum radiatum) evoked by electric stimulation $\left(S_{0}\right)$ of the Schaffer fibers. $\boldsymbol{b}$ Averaged time courses of changes in fEPSP slope induced by application of $30 \mathrm{~nm}$ galanin alone. $c$, Averaged time course of changes in fEPSP slope induced by application of 20 nM SKF 38393 alone. d, Averaged time courses of the effect of galanin ( $30 \mathrm{nm)} \mathrm{in} \mathrm{the}$ presence of the $D_{1}$-like receptor agonist SKF $38393(20 \mathrm{~nm}$; $)$ or in the presence of both SKF $38393(10 \mathrm{~nm})$ and the $D_{1}$-like receptor antagonist SCH23390 ( $1 \mu \mathrm{m}$; O). SKF 38393 was applied at least 30 min before galanin application, and SCH 23390 was applied 30 min before SKF 38393 application. $\boldsymbol{e}$, Recordings obtained from representative experiments, where each trace is the average of eight consecutive responses obtained in absence (1) and presence (2) of galanin ( $30 \mathrm{~nm}$; left), in absence (3) and presence (4) of SKF 38393 ( $20 \mathrm{~nm}$; middle), and in absence (5) and presence (6) of galanin ( $30 \mathrm{~nm}$ ) when the slice was incubated with SKF 38393 (20 nm; right) are shown $D_{1}$-like; each trace is composed of the stimulus artifact followed by the presynaptic volley and the fEPSP. Superimposed recordings were obtained from the same slice at the time points indicated in $\boldsymbol{b}$ - $\boldsymbol{d}$. Note the inhibitory effect of galanin in $\boldsymbol{b}$ (absence of SKF 38393) and facilitatory effect in $\boldsymbol{d}$ (presence of SKF 38393). $\boldsymbol{f}$, Comparison between the averaged effects of galanin on hippocampal synaptic transmission in presence of SKF 38393 and in the presence of both SKF 38393 and SCH 23390. The ordinates show the percent change of fEPSP slope induced by galanin ( $30 \mathrm{~nm}$ ) $50-60$ min after its application to hippocampal slices not treated or treated with SKF 38393 and treated with both SKF 38393 and SCH 23390, as indicated below each bar. $\theta, p<0.05$ (one-way ANOVA with Bonferroni's correction) as compared with absence of galanin in the same slices; $\varphi, p<$ 0.05 (one-way ANOVA with the Bonferroni's correction) as compared with galanin alone. All values are mean \pm SEM [100\%, averaged fEPSP slopes at times -10 to $0: \boldsymbol{d},-0.69 \pm 0.073 \mathrm{mV} / \mathrm{ms}, n=8(\boldsymbol{O}) ;-0.66 \pm 0.103 \mathrm{mV} / \mathrm{ms}, n=6(\bigcirc) ; \boldsymbol{b}$, $-0.69 \pm 0.023 \mathrm{mV} / \mathrm{ms}, n=9 ; c,-0.64 \pm 0.041 \mathrm{mV} / \mathrm{ms}, n=7]$.

cross-antagonism was therefore used as a "biochemical fingerprint" of the $\mathrm{D}_{1}$-like- $\mathrm{Gal}_{1}$ receptor heteromer. Using these criteria and measuring MAPK activation as an endpoint, we were able to identify $\mathrm{D}_{1}$-like- $\mathrm{Gal}_{1}$ receptor heteromers in the ventral, but not the dorsal, hippocampus.

Although the existence of $\mathrm{Gal}_{1}$ receptors on septohippocampal cholinergic neurons has been questioned previously (Miller et al., 1997), our observations of the same qualitative cross talk in signaling in synaptosomal preparations as in cells expressing $\mathrm{D}_{1}$-like and $\mathrm{Gal}_{1}$ receptors strongly suggests that functional $\mathrm{Gal}_{1}$ receptors are present in cholinergic terminals of the ventral hippocampus. As mentioned above, in transfected cells, $\mathrm{D}_{1}$-like receptor stimulation potentiates 

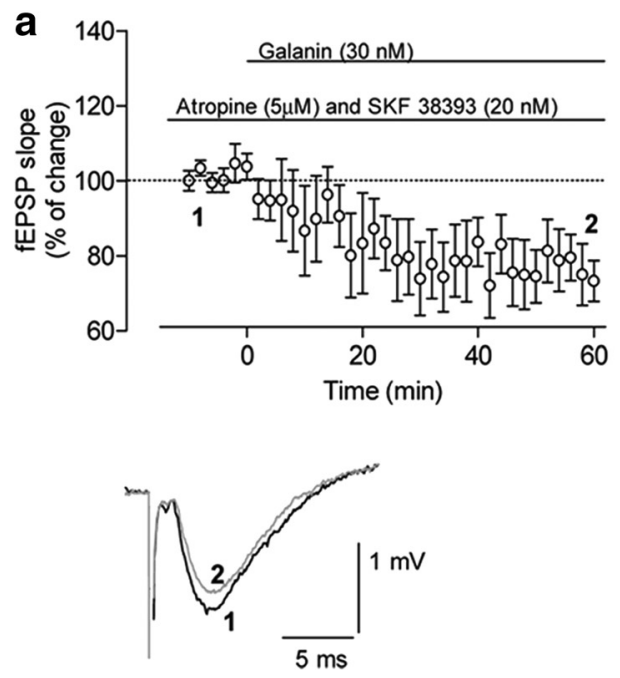

Figure 10. Effect of muscarinic receptor blockade on the dopamine-dependent galanin-mediated modulation of synaptictransmission in the ventral hippocampus. $\boldsymbol{a}$, Top, Averaged time courses of the effect of galanin $(30 \mathrm{~nm})$ in the presence of both the $\mathrm{D}_{1}$-like receptor agonist SKF $38393(20 \mathrm{~nm})$ and the muscarinic acetylcholine receptor antagonist atropine $(5 \mu \mathrm{M})$. SKF 38393 was applied at least 60 min before galanin, and atropine was applied 30 min before SKF 38393 . Bottom, Traces obtained with a representative experiment; each trace is the average of eight consecutive responses obtained immediately before (1) and during (2) galanin application, and is composed of the stimulus artifactfollowed by the presynaptic volley and the fEPSP. $\boldsymbol{b}$, Comparison between the averaged effects of galanin ( $30 \mathrm{~nm}$ for 50 - 60 $\mathrm{min}$ ) in the absence of drugs and in the presence of both SKF 38393 and atropine. The averaged effects of atropine and both atropine and SKF 38393 are also shown; $\theta, p<0.05$ (Student's ttest) compared with absence of galanin in the same slices; $\varphi, p<0.05$ (Student'sttest) compared with both atropine and SKF 38393 present in the same slices. All values are shown as the mean \pm SEM ( $100 \%$, averaged fEPSP slopes at times $-10-0: \boldsymbol{a},-0.60 \pm 0.037 \mathrm{mV} / \mathrm{ms} ; n=6)$.

a

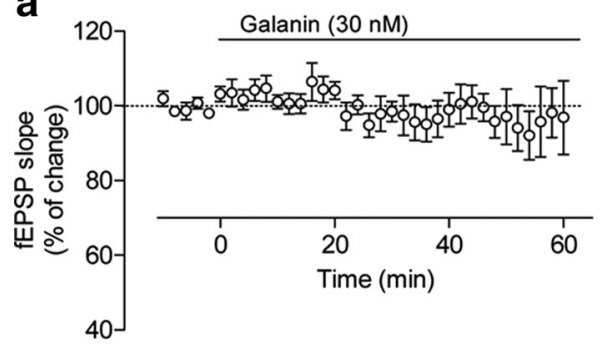

C

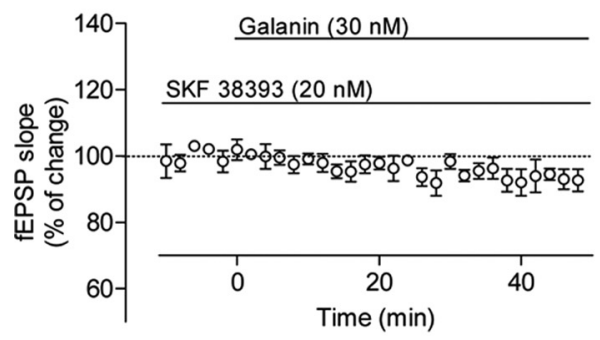

b

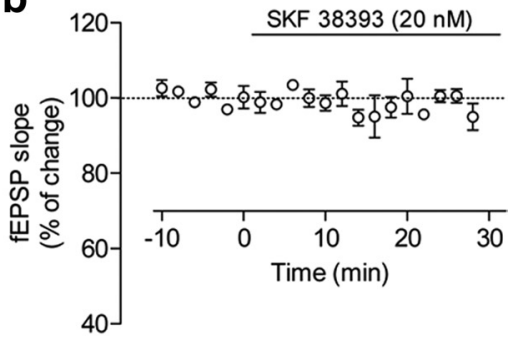

d

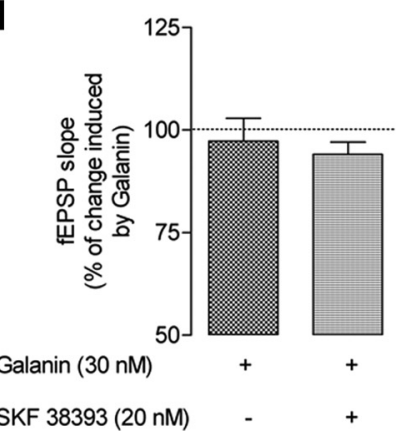

Figure 11. Lack of effect of galanin on synaptic transmission in the dorsal hippocampus. $\boldsymbol{a}, \boldsymbol{b}$, Averaged time course of changes in fEPSP slope induced by application of $30 \mathrm{~nm}$ galanin (a) or $20 \mathrm{~mm}$ SKF 38393 (b). $\boldsymbol{c}$, Averaged time courses of the effect of galanin $\left(30 \mathrm{~nm}\right.$ ) in the presence of the $\mathrm{D}_{1}$-like receptor agonist SKF 38393 (20 nM). SKF 38393 was applied at least 30 min before galanin; ordinates show the percent change offEPSP slope induced by galanin ( $30 \mathrm{~nm}) 50-60$ min after its application to hippocampal slices not treated and treated with SKF 38393, as indicated below each bar. All values are shown as the mean \pm SEM $(100 \%$, averaged fEPSP slopes at times $-10-0: \boldsymbol{a},-0.55 \pm 0.070 \mathrm{mV} / \mathrm{ms}, n=5 ; \boldsymbol{b},-0.58 \pm 0.048 \mathrm{mV} / \mathrm{ms}, n=3 ; \boldsymbol{c},-0.55 \pm 0.064 \mathrm{mV} / \mathrm{ms}$, $n=3)$. $\boldsymbol{d}$, Comparison between the averaged effects of galanin in the presence and absence of SKF 38393 .

the effects of $\mathrm{Gal}_{1}$ but not $\mathrm{Gal}_{2}$ receptor activation, but $\mathrm{Gal}_{1}$ receptor stimulation does not modify $\mathrm{D}_{1}$-like receptor-mediated signaling. In hippocampal synaptosomal preparations at nanomolar concentrations, neither galanin nor a $\mathrm{D}_{1}$-like receptor agonist produced any modification of $\mathrm{K}^{+}$-induced ACh release. Nevertheless, previous activation of $\mathrm{D}_{1}$-like receptors triggered a facilitatory effect of galanin. Also as in transfected cells, galanin did not modify the lack of effect of a $D_{1}$-like receptor agonist. Since $D_{5}$ predominates over $\mathrm{D}_{1}$ receptors in the hippocampus (Ciliax et al., 2000), and $\mathrm{D}_{5}$ receptors have been shown previously to be involved in the modulation of hippocampal ACh release (Hersi et al., 2000; Laplante et al., 2004b), $D_{5}$ is probably the main $D_{1}$-like receptor subtype forming heteromers with $\mathrm{Gal}_{1}$ receptors in cholinergic terminals of the ventral hippocampus.

In previous studies, galanin generally showed an inhibitory effect on hippocampal cholinergic neurotransmission (Fisone et al., 1987; Ögren et al., 1998; Laplante et al., 2004a). However, most of these studies were performed with in vivo microdialysis techniques using much higher (micromolar) concentrations of galanin than in the present experiments (Ögren et al., 1998; Laplante et al., 2004a) and with artificially increased extracellular concentrations of ACh because of the addition of acetylcholinesterase inhibitors in the perfusion medium. The use of acetylcholinesterase inhibitors in the dialysis medium has raised concerns about the possibility of not only quantitative but also qualitative artifactual results (DeBoer and Abercrombie, 1996; Acquas and Fibiger, 1998). At the level of the Shaffer-CA1 glutamatergic synapses of the ventral hippocampus, a low (nanomolar) concentration of galanin was inhibitory providing that dopamine receptors were not activated. This result is in accordance with the expression of $\mathrm{Gal}_{1}$ receptors in the CA1 area of the ventral hippocampus (O'Donnell et al., 1999). In fact, we found galanin to be completely ineffective in the dorsal hippocampus. This cholinergic-independent depressant effect of galanin could be related to its ability to decrease neuronal hippocampal glutamatergic neurotransmission (Zini et al., 1993; Mazarati et al., 2000). Also, galanin has been reported to inhibit LTP in the Shaffer-CA1 glutamatergic synapses (Sakurai et al., 1996). The $D_{1}$-like receptor agonist, which was ineffective when administered alone, turned an inhibitory effect of galanin into an excitatory effect, and this interaction depended on cholinergic neurotransmission, since it was completely blocked by a muscarinic ACh receptor antagonist. From our results from ventral hippocampal synaptosomal preparations and slices, a model of the role of galanin in the Shaffer-CA1 synapses of the ventral hippocampus can be proposed: an isolated increase in the activity of the septohippocampal cholinergic input produces a modest release of ACh and galanin. This 
modest release of galanin would, nevertheless, be sufficient to inhibit the excitability of glutamatergic synapses by acting on presynaptic or postsynaptic galanin receptors. However, with a concomitant increase in the activity of the ventral tegmental area (VTA)-hippocampal dopaminergic input, coactivation of $\mathrm{D}_{1}$-like and galanin receptors localized in cholinergic terminals induces a strong release of ACh, which overcomes the inhibitory role of galanin and leads to increased excitability of the glutamatergic synapses.

The interactions reported here occur in the ventral but not in the dorsal hippocampus. These two hippocampal areas have differential efferent connections with the rest of the brain, such that the dorsal hippocampus is primarily connected with the neocortex, whereas the ventral hippocampus is connected to subcortical structures, such as the hypothalamus and the amygdala (Naber and Witter, 1998). Since both the amygdala and the hypothalamus control the activity of the hypothalamus-pituitary-adrenal axis, it is therefore not a surprise that a major function of the ventral hippocampus is the processing of information related to emotion-related behaviors, as increasing evidence now indicates (Segal et al., 2010). Interestingly, injection of acetylcholine into the ventral, but not the dorsal, hippocampus, reduces anxiety (Degroot and Treit, 2004). One can therefore speculate that the cholinergic-dependent facilitatory action of galanin on excitatory Schaffer-CA1 synapses (a last relay of the excitatory output of the hippocampus) may influence the control of anxiety and emotional memory.

Altogether, our results strongly suggest that $\mathrm{D}_{1}$-like-Gal ${ }_{1}$ receptor heteromers that are localized in cholinergic nerve terminals play an important role in the modulation of cholinergic neurotransmission in the ventral hippocampus. Receptor heteromers are becoming the focus of extensive research in the field of GPCRs, and we are just starting to understand the mechanisms involved in heteromerization and its functional meaning (Bulenger et al., 2005; Ferré et al., 2007; Dalrymple et al., 2008; Milligan, 2009; Rozenfeld and Devi, 2010). The present study provides a clear example of a receptor heteromer acting as a processor that integrates signals of different neurotransmitters and modulates cell signaling and neuronal function (Ferré et al., 2007). Since receptor heteromers are increasingly being considered as pharmacological targets (George et al., 2002; Ferré et al., 2010), $\mathrm{D}_{1}-\mathrm{Gal}_{1}$ and $\mathrm{D}_{5}-\mathrm{Gal}_{1}$ receptor heteromers could be considered targets for drugs useful in Alzheimer's disease, in view of the involvement of the septohippocampal cholinergic system in this disease (Ögren et al., 1998; Mitsukawa et al., 2008). Importantly, $\mathrm{D}_{1}, \mathrm{D}_{5}$, and $\mathrm{Gal}_{1}$ receptors are also colocalized in brain areas other than the hippocampus, such as the mesencephalic dopaminergic nuclei substantia nigra and the VTA (Schilström et al., 2006; Picciotto, 2008). If $\mathrm{D}_{1}$-like-Gal ${ }_{1}$ receptor heteromers are also present in the mesencephalic dopaminergic cells, they could be targets for the treatment of dopamine-related neuropsychiatric disorders, including drug addiction. Finally, the ability of galanin receptors to heteromerize with other GPCRs in other regions of the CNS could explain pharmacological findings that have so far been difficult to explain, such as the well-known biphasic dose-dependent effect of galanin on nociception (Xu et al., 2008).

\section{References}

Acquas E, Fibiger HC (1998) Dopaminergic regulation of striatal acetylcholine release: the critical role of acetylcholinesterase inhibition. J Neurochem 70:1088-1093.

Anderson WW, Collingridge GL (2001) The LTP Program: a data acquisition program for on-line analysis of long-term potentiation and other synaptic events. J Neurosci Methods 108:71-83.
Branchek TA, Smith KE, Gerald C, Walker MW (2000) Galanin receptor subtypes. Trends Pharmacol Sci 21:109-117.

Bulenger S, Marullo S, Bouvier M (2005) Emerging role of homo- and heterodimerization in G-protein-coupled receptor biosynthesis and maturation. Trends Pharmacol Sci 26:131-137.

Carriba P, Ortiz O, Patkar K, Justinova Z, Stroik J, Themann A, Müller C, Woods AS, Hope BT, Ciruela F, Casadó V, Canela EI, Lluis C, Goldberg SR, Moratalla R, Franco R, Ferré S (2007) Striatal adenosine A2A and cannabinoid CB1 receptors form functional heteromeric complexes that mediate the motor effects of cannabinoids. Neuropsychopharmacology $32: 2249-2259$.

Ciliax BJ, Nash N, Heilman C, Sunahara R, Hartney A, Tiberi M, Rye DB, Caron MG, Niznik HB, Levey AI (2000) Dopamine D(5) receptor immunolocalization in rat and monkey brain. Synapse 37:125-145.

Counts SE, Perez SE, Mufson EJ (2008) Galanin in Alzheimer's disease: neuroinhibitory or neuroprotective? Cell Mol Life Sci 65:1842-1853.

Crawley JN (1996) Minireview. Galanin-acetylcholine interactions: relevance to memory and Alzheimer's disease. Life Sci 58:2185-2199.

Dalrymple MB, Pfleger KD, Eidne KA (2008) G protein-coupled receptor dimers: functional consequences, disease states and drug targets. Pharmacol Ther 118:359-371.

DeBoer P, Abercrombie ED (1996) Physiological release of striatal acetylcholine in vivo: modulation by D1 and D2 dopamine receptor subtypes. J Pharmacol Exp Ther 277:775-783.

Degroot A, Treit D (2004) Anxiety is functionally segregated within the septo-hippocampal system. Brain Res 1001:60-71.

Diógenes MJ, Fernandes CC, Sebastião AM, Ribeiro JA (2004) Activation of adenosine A2A receptor facilitates brain-derived neurotrophic factor modulation of synaptic transmission in hippocampal slices. J Neurosci 24:2905-2913.

Ferrada C, Moreno E, Casadó V, Bongers G, Cortés A, Mallol J, Canela EI, Leurs R, Ferré S, Lluís C, Franco R (2009) Marked changes in signal transduction upon heteromerization of dopamine D1 and histamine H3 receptors. Br J Pharmacol 157:64-75.

Ferré S, Ciruela F, Woods AS, Lluis C, Franco R (2007) Functional relevance of neurotransmitter receptor heteromers in the central nervous system. Trends Neurosci 30:440-446.

Ferré S, Baler R, Bouvier M, Caron MG, Devi LA, Durroux T, Fuxe K, George SR, Javitch JA, Lohse MJ, Mackie K, Milligan G, Pfleger KD, Pin JP, Volkow ND, Waldhoer M, Woods AS, Franco R (2009) Building a new conceptual framework for receptor heteromers. Nat Chem Biol 5:131-134.

Ferré S, Navarro G, Casadó V, Cortés A, Mallol J, Canela EI, Lluís C, Franco R (2010) G protein-coupled receptor heteromers as new targets for drug development. Prog Mol Biol Transl Sci 91:41-52.

Fisone G, Wu CF, Consolo S, Nordström O, Brynne N, Bartfai T, Melander T, Hökfelt T (1987) Galanin inhibits acetylcholine release in the ventral hippocampus of the rat: histochemical, autoradiographic, in vivo, and in vitro studies. Proc Natl Acad Sci U S A 84:7339-7343.

George SR, O’Dowd BF, Lee SP (2002) G-protein-coupled receptor oligomerization and its potential for drug discovery. Nat Rev Drug Discov $1: 808-820$.

Hawes JJ, Picciotto MR (2005) Characterization of GalR1, GalR2, and GalR3 immunoreactivity in catecholaminergic nuclei of the mouse brain. J Comp Neurol 2004 479:410-423. Erratum in: J Comp Neurol 2005 490:98-100.

Hersi AI, Richard JW, Gaudreau P, Quirion R (1995) Local modulation of hippocampal acetylcholine release by dopamine $\mathrm{D}_{1}$ receptors: a combined receptor autoradiography and in vivo dialysis study. J Neurosci 15:7150-7157.

Hersi AI, Kitaichi K, Srivastava LK, Gaudreau P, Quirion R (2000) Dopamine D-5 receptor modulates hippocampal acetylcholine release. Mol Brain Res 76:336-340.

Hökfelt T, Xu ZQ, Shi TJ, Holmberg K, Zhang X (1998) Galanin in ascending systems. Focus on coexistence with 5-hydroxytryptamine and noradrenaline. Ann N Y Acad Sci 863:252-263.

Lang R, Gundlach AL, Kofler B (2007) The galanin peptide family: receptor pharmacology, pleiotropic biological actions, and implications in health and disease. Pharmacol Ther 115:177-207.

Laplante F, Crawley JN, Quirion R (2004a) Selective reduction in ventral hippocampal acetylcholine release in awake galanin-treated rats and galanin-overexpressing transgenic mice. Regul Pept 122:91-98. 
Laplante F, Sibley DR, Quirion R (2004b) Reduction in acetylcholine release in the hippocampus of dopamine D5 receptor-deficient mice. Neuropsychopharmacology 29:1620-1627.

Lee FJ, Xue S, Pei L, Vukusic B, Chéry N, Wang Y, Wang YT, Niznik HB, Yu XM, Liu F (2002) Dual regulation of NMDA receptor functions by direct protein-protein interactions with the dopamine D1 receptor. Cell 111:219-230.

Liu F, Wan Q, Pristupa ZB, Yu XM, Wang YT, Niznik HB (2000) Direct protein-protein coupling enables cross-talk between dopamine D5 and gamma-aminobutyric acid A receptors. Nature 403:274-280.

Mazarati AM, Hohmann JG, Bacon A, Liu H, Sankar R, Steiner RA, Wynick D, Wasterlain CG (2000) Modulation of hippocampal excitability and seizures by galanin. J Neurosci 20:6276-6281.

Melander T, Staines WA, Hökfelt T, Rökaeus A, Eckenstein F, Salvaterra PM, Wainer BH (1985) Galanin-like immunoreactivity in cholinergic neurons of the septum-basal forebrain complex projecting to the hippocampus of the rat. Brain Res 360:130-138.

Melander T, Hökfelt T, Rökaeus A, Cuello AC, Oertel WH, Verhofstad A, Goldstein M (1986a) Coexistence of galanin-like immunoreactivity with catecholamines, 5-hydroxytryptamine, GABA and neuropeptides in the rat CNS. J Neurosci 6:3640-3654.

Melander T, Staines WA, Rökaeus A (1986b) Galanin-like immunoreactivity in hippocampal afferents in the rat, with special reference to cholinergic and noradrenergic inputs. Neuroscience 19:223-240.

Miller MA, Kolb PE, Raskind MA (1997) GALR1 galanin receptor mRNA is coexpressed by galanin neurons but not cholinergic neurons in the rat basal forebrain. Brain Res Mol Brain Res 52:121-129.

Milligan G (2009) G protein-coupled receptor hetero-dimerization: contribution to pharmacology and function. Br J Pharmacol 158:5-14.

Mitsukawa K, Lu X, Bartfai T (2008) Galanin, galanin receptors and drug targets. Cell Mol Life Sci 65:1796-1805.

Naber PA, Witter MP (1998) Subicular efferents are organized mostly as parallel projections: a double-labeling, retrograde-tracing study in the rat. J Comp Neurol 393:284-297.

Navarro G, Moreno E, Aymerich M, Marcellino D, McCormick PJ, Mallol J, Cortés A, Casadó V, Canela EI, Ortiz J, Fuxe K, Lluís C, Ferré S, Franco R (2010) Direct involvement of $\sigma$ l receptors in the dopamine D1 receptor-mediated effects of cocaine. Proc Natl Acad Sci U S A 107:18676-18681.

Neumeyer JL, Kula NS, Bergman J, Baldessarini RJ (2003) Receptor affini- ties of dopamine D1 receptor-selective novel phenylbenzazepines. Eur J Pharmacol 474:137-140.

O'Donnell D, Ahmad S, Wahlestedt C, Walker P (1999) Expression of the novel galanin receptor subtype GALR2 in the adult rat CNS: distinct distribution from GALR1. J Comp Neurol 409:469-481.

Ögren SO, Schött PA, Kehr J, Yoshitake T, Misane I, Mannström P, Sandin J (1998) Ann N Y Acad Sci 863:342-363.

Ögren SO, Kuteeva E, Elvander-Tottie E, Hökfelt T (2010) Neuropeptides in learning and memory processes with focus on galanin. Eur J Pharmacol 626:9-17.

Parker EM, Izzarelli DG, Nowak HP, Mahle CD, Iben LG, Wang J, Goldstein ME (1995) Cloning and characterization of the rat GALR1 galanin receptor from Rin14B insulinoma cells. Mol Brain Res 34:179-189.

Picciotto MR (2008) Galanin and addiction. Cell Mol Life Sci 65:1872-1879.

Rozenfeld R, Devi LA (2010) Exploring a role for heteromerization in GPCR signalling specificity. Biochem J 433:11-18.

Sakurai E, Maeda T, Kaneko S, Akaike A, Satoh M (1996) Galanin inhibits long-term potentiation at Schaffer collateral-CA1 synapses in guinea-pig hippocampal slices. Neurosci Lett 212:21-24.

Schilström B, Yaka R, Argilli E, Suvarna N, Schumann J, Chen BT, Carman M, Singh V, Mailliard WS, Ron D, Bonci A (2006) Cocaine enhances NMDA receptor-mediated currents in ventral tegmental area cells via dopamine D5 receptor-dependent redistribution of NMDA receptors. J Neurosci 26:8549-8558.

Seeman P, Van Tol HH (1994) Dopamine receptor pharmacology. Trends Pharmacol Sci 15:264-270.

Segal M, Richter-Levin G, Maggio N (2010) Stress-induced dynamic routing of hippocampal connectivity: A hypothesis. Hippocampus 20:1332-1338.

Vaz SH, Cristóvão-Ferreira S, Ribeiro JA, Sebastião AM (2008) Brainderived neurotrophic factor inhibits GABA uptake by the rat hippocampal nerve terminals. Brain Res 1219:19-25.

Wang HY, Wild KD, Shank RP, Lee DHS (1999) Galanin inhibits acetylcholine release from rat cerebral cortex via pertussis toxin-sensitive Gi protein. Neuropeptides 33:197-205.

Xu XJ, Hökfelt T, Wiesenfeld-Hallin Z (2008) Galanin and spinal pain mechanisms: where do we stand in 2008? Cell Mol Life Sci 65:1813-1819.

Zini S, Roisin MP, Langel U, Bartfai T, Ben-Ari Y (1993) Galanin reduces release of endogenous excitatory amino acids in the rat hippocampus. Eur J Pharmacol 245:1-7. 